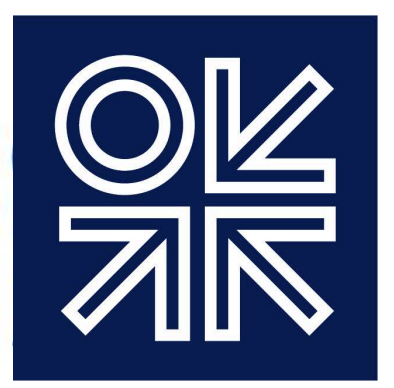

THE OXFORD

INSTITUTE

FOR ENERGY

STUDIES

May 2018

\title{
The rise of renewables and energy transition: what adaptation strategy for oil companies and oil-exporting countries?
}

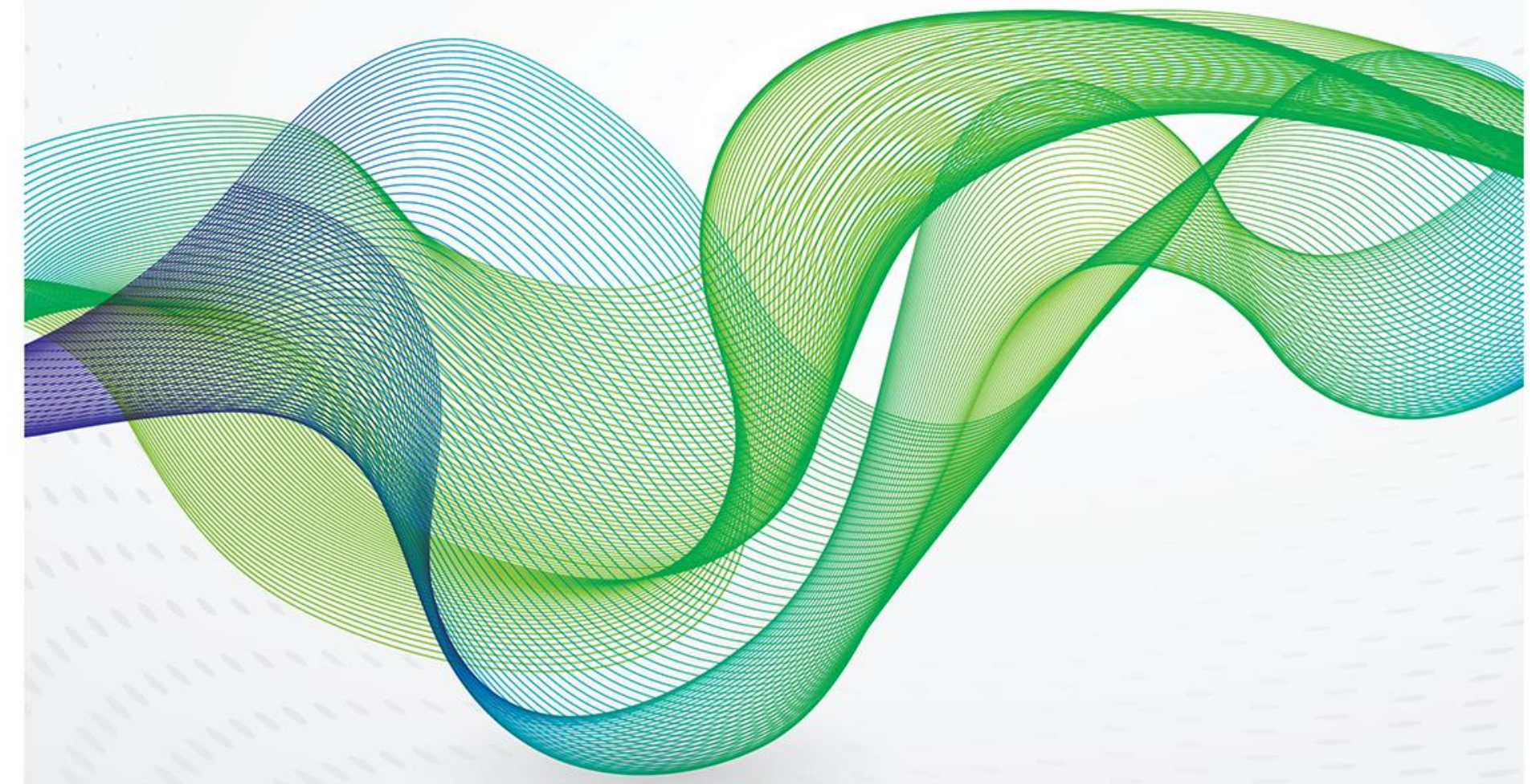



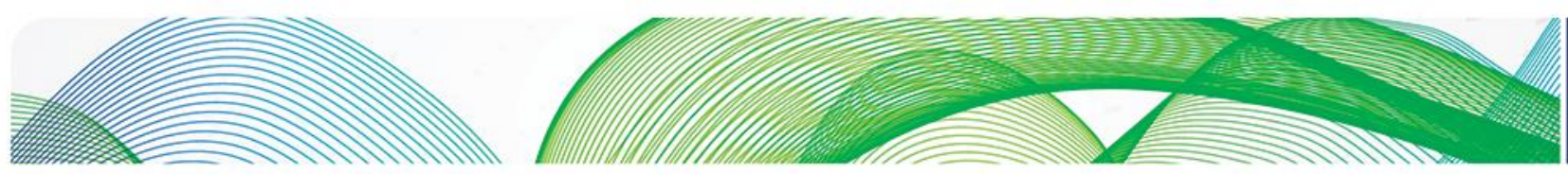

\section{잊조}

The contents of this paper are the authors' sole responsibility. They do not necessarily represent the views of the Oxford Institute for Energy Studies or any of its members.

\section{Copyright $\odot 2018$}

\section{Oxford Institute for Energy Studies}

(Registered Charity, No. 286084)

This publication may be reproduced in part for educational or non-profit purposes without special permission from the copyright holder, provided acknowledgment of the source is made. No use of this publication may be made for resale or for any other commercial purpose whatsoever without prior permission in writing from the Oxford Institute for Energy Studies.

ISBN 978-1-78467-109-9

DOI: https://doi.org/10.26889/ 9781784671099

OIES is grateful to the Kuwait Foundation for the Advancement of Sciences for funding support. 

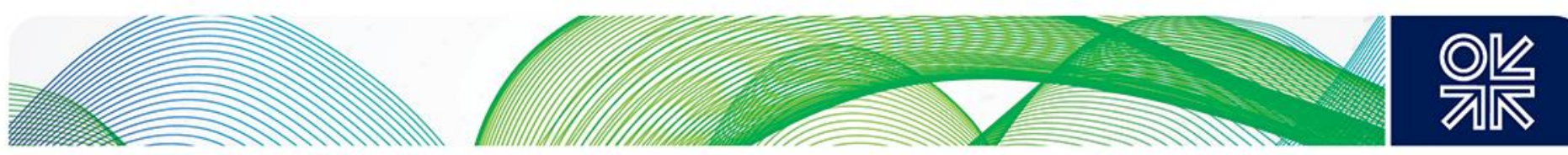

\section{Contents}

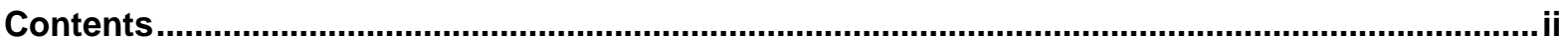

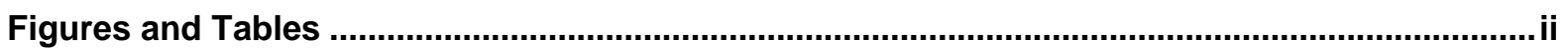

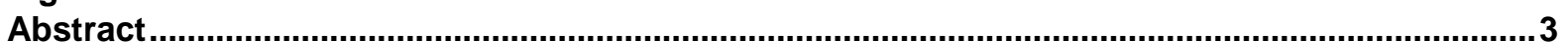

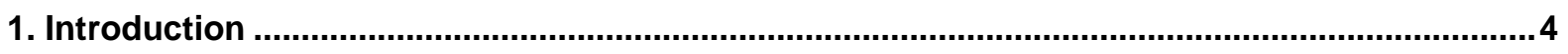

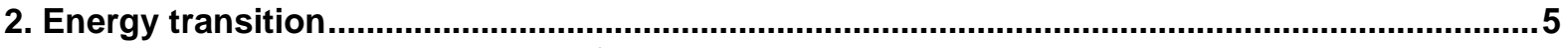

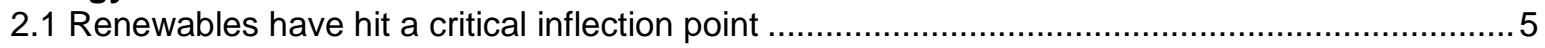

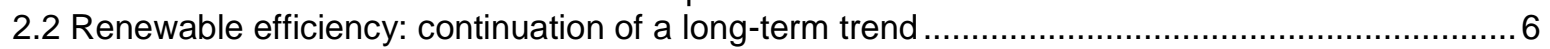

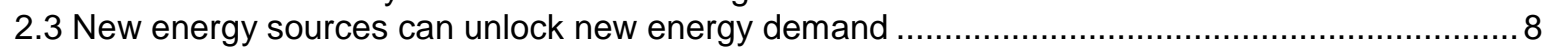

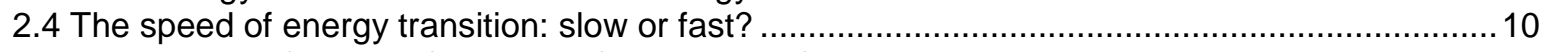

2.5 Implications of speed of transition for disrupted fuels ......................................................... 14

3. Implications for the strategy of oil companies and oil-exporting countries: the role of

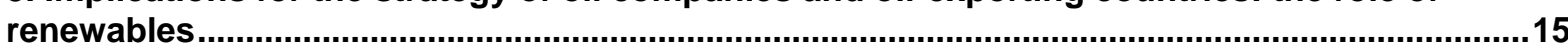

3.1 Adaptation strategy for international oil companies and the role of renewables .......................16

3.2 Adaptation strategy for oil-exporting countries and the role of renewables ..............................19

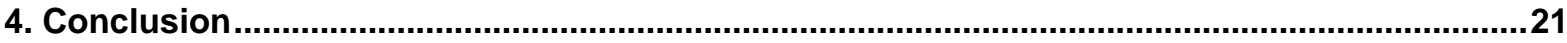

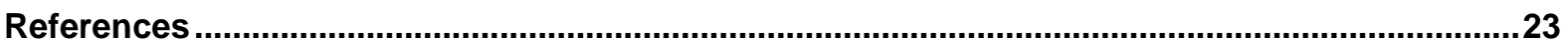

\section{Figures and Tables}

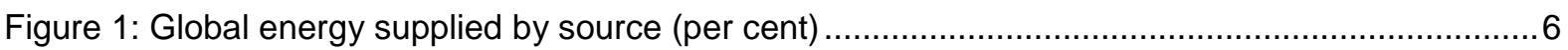

Figure 2: Conversion of primary energy supply into consumable energy ........................................... 8

Figure 4: Global energy supplied by source ..............................................................................11

Figure 5: Hirfendahl-Hirschman concentration index of global energy supplies .................................14

Figure 6: Estimated free cash flow profile of seven Statoil renewables projects ...............................19

Table 1: Recent costs of usable kWh of energy by source ............................................................

Table 2: Very long-run outlook and adaptation strategies for oil and gas ........................................17

Table 3: Countries where solar projects can liberate gas volumes ...................................................18

Table 4: Table of assumptions for solar investment that also liberates marketing gas ........................20 

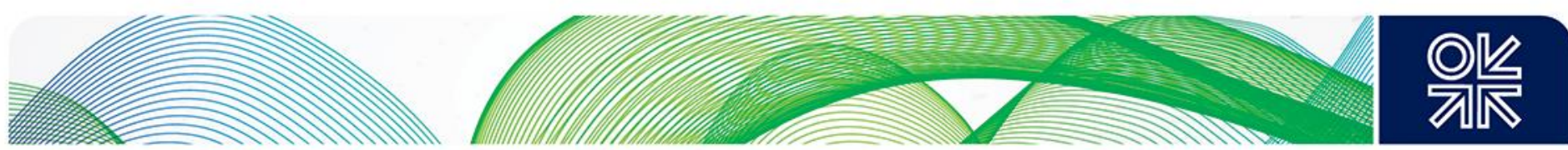

\begin{abstract}
The energy landscape is changing rapidly with far-reaching implications for global energy industries and actors, including oil companies and oil-exporting countries. These rapid changes introduce uncertainty in multiple dimensions, the most important of which is the speed of transition. While the transformation of energy systems is rapid in certain regions of the world, such as Europe, the speed of global energy transition remains uncertain. It is also difficult to define the end game (which technology will win and what the final energy mix will be), as the outcome of transition will vary across regions. A key issue facing oil companies and oil-exporting countries is how they should now position themselves and how best to be part of the renewables 'revolution'. For oil companies, moving beyond their core business is risky, but a 'wait-and-see' strategy could be costly, therefore oil companies need to gradually 'extend' their business model and rather than a complete shift from hydrocarbons to renewables, they should aim to build an integrated portfolio which includes both hydrocarbon and lowcarbon assets. The strategies designed to make this happen need to be flexible and able to evolve quickly in response to anticipated changes in the market. For oil-exporting countries, with subsidized prices and rising domestic energy consumption, there is no conflict between investing in renewables and in hydrocarbons as these countries can liberate oil and gas for export markets, improving the economics of renewables projects. In the long run, however, the main challenge for many oil exporting countries is economic diversification as it is the ultimate safeguard against the energy transition. Whether or not these countries succeed in their goal of achieving a diversified economy has implications for global energy markets and the speed of global energy transformations. In other words, the global energy transition will not only shape political and economic outcomes in oilexporting countries, but the transformations in these major oil-exporting countries will, in turn, shape the global energy transition - adding another layer of uncertainty to the already complex phenomenon of energy transition.
\end{abstract}

Keywords: Energy transition, renewables, oil companies, oil exporting countries, business strategy, peak oil demand 

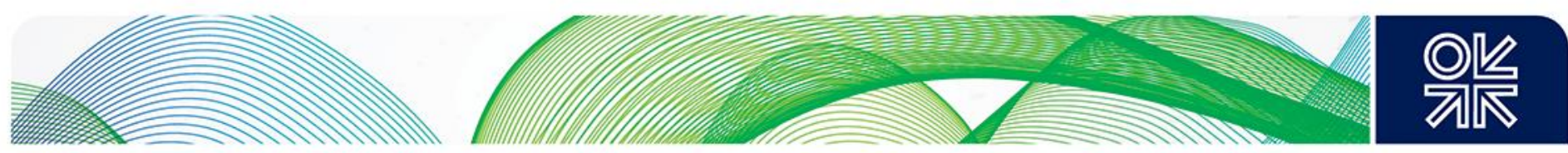

\section{Introduction}

The energy landscape is rapidly changing with wide-reaching implications for global energy industries and actors, including oil companies and oil-exporting countries. While there are many uncertainties induced by the energy transition, there is almost a consensus among forecasts provided by various organizations that the share of renewables in the energy mix will rise (International Energy Agency, 2017; BP, 2018). In fact, renewable energy's recent cost deflation has been nothing short of revolutionary for the global energy industry. Five years ago, US wind costs were $\$ 11 \mathrm{c} / \mathrm{kWh}$ (US cents per kilowatt hour) and solar costs were $\$ 17 \mathrm{c} / \mathrm{kWh}$, on a fully loaded basis, including the capital costs of construction. Neither was commercial without subsidies. The International Renewable Energy Agency (IRENA) (2018) estimates that global average cost for onshore wind and solar has now declined to $\$ 5 \mathrm{c} / \mathrm{kWh}$ and $\$ 6 \mathrm{c} / \mathrm{kWh}$ respectively. A new record was set in 2016 , with a $\$ 2.4 \mathrm{c} / \mathrm{kWh}$ bid in the UAE. It was broken in October 2017 with a $\$ 1.8 \mathrm{c} / \mathrm{kWh}$ bid by Masdar and EDF for Saudi Arabia's $300 \mathrm{MW}$ Sakaka plant. Wind power costs have also declined, and further deflation to $\$ 4$ $\mathrm{c} / \mathrm{kWh}$ by 2020 is within striking distance. As a result, on a plant-level basis and excluding the cost of dealing with intermittency, wind and solar have emerged as very competitive sources of energy globally.

As the energy transition is expected to lead to structural changes in energy markets around the globe, oil companies and oil-exporting countries face serious challenges. The challenge for oil companies is the disruption of their business models and how to integrate low-carbon assets into their portfolios, whereas oil-exporting countries with proved reserves-to-production ratios of multiple decades face the challenge of monetizing their large reserve base and the risk of losses in export revenues, which could disrupt their socio-economic wellbeing, given the high reliance of their budget on oil revenues. Therefore, a key question is, how should oil companies and oil-exporting countries position themselves in the transition era in order to be part of the renewables 'revolution' and ensure long-term sustainability?

A successful adaptation strategy requires understanding the nature of energy transition. This is because decisions on business model adaptation and investment strategy require knowing how fast the transition will happen, which technologies will eventually prevail, and how the final energy mix will look after the transition is completed. The oil companies are faced with a strategic dilemma here. If they postpone their adaptation strategy until there is less uncertainty, they may create a window of opportunity for their competitors. On the other hand, early investment decisions or investment in 'losing' technologies would not only limit their future options but also increase the risk of asset writeoffs. Oil-exporting countries face similar strategic dilemmas as the transition entails structural transformations in their energy sector and the overall economy, and the allocation of scarce resources towards new sectors, including renewables, which don't generate the sizeable rents that the oil and gas industry does.

This paper sheds some new light on the issue of energy transition and adaptation strategy for oil companies and oil-exporting countries. We argue that while the energy transition is happening very fast in some regions, such as the EU, the speed of the global energy transition is highly uncertain. Historical evidence points to a slow energy transition, which is instructive but not necessarily predictive. Furthermore, the current transition is being managed and coordinated through government policy aimed at decarbonization and reducing air pollution, whereas past transitions happened mostly naturally or accidentally without strong policy support. This means that the drivers of the current transition are fundamentally different from the past transformations and this induces uncertainty about how events could unfold.

Given the uncertainty in the speed of transition we argue that oil companies need to adopt a strategy that is likely to be successful under a wide set of future market conditions. We acknowledge that moving beyond core business is risky for oil companies but at the same time a 'wait-and-watch' strategy can be costly. Instead, oil companies need to gradually 'extend' their business model rather than completely 'shift' from hydrocarbons to renewables. This business model extension implies 

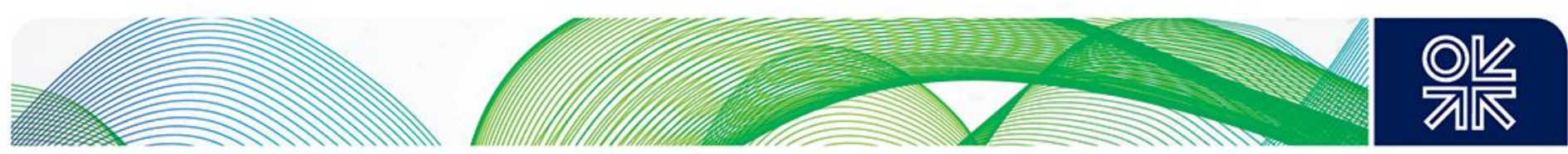

building an integrated portfolio, including both hydrocarbon and low-carbon technologies assets. Given that the endgame (in terms of winning technologies) is unclear, oil companies should focus on a combination of competing low-carbon technologies rather than investing in a specific technology.

With regards to oil-exporting countries, the adaptation strategy is different. There is no conflict between renewable investment and hydrocarbon business in these countries. This is because these countries can liberate oil and gas for export through investment in alternative technologies. This will be more pronounced when considering that oil-exporting countries are at a stage of development in which their economic growth is tied with energy consumption and thus domestic energy consumption is expected to rise, reducing their export capacity. We show that at current oil and gas prices, investment in solar is a viable option in the Middle East oil-exporting countries. The economics of renewables in oil-exporting countries will be susceptible to oil price cycles; nonetheless, when the gains from liberated hydrocarbon are taken into account, this investment rationale is reinforced. We argue that although renewable investment can boost the short-term export revenue of oil-exporting countries, it is not a long-term solution against the potential disruption in global oil demand growth. In the long run, diversification of their economies is the main strategy that can shield these countries from the effects of energy transition. During the transition, the oil sector will play a dominant role in the economy of these countries but is expected to start declining if the objective of diversification is achieved. Furthermore, the success or failure of oil-exporting countries in their goal of achieving a diversified economy will also influence the speed of global energy transition (through its impact on oil prices), adding more layers of complexity and uncertainty.

\section{Energy transition}

Energy transition is a radical shift in the energy system from an existing model to a new paradigm. It is complex and goes beyond only the replacement of one source of fuel with another. In essence, energy transition involves changes in three interrelated dimensions (Sovacool and Geels, 2016): (i) the tangible elements of the energy system, which include technology, infrastructure, market, production equipment, consumption patterns and distribution chains ${ }^{1}$; (ii) actors and their conduct, which comprise new strategies and investment patterns, as well as changing coalitions and capabilities of actors; and (iii) socio-technical regimes that contain formal regulations and policies, institutions as well as mindset and belief systems, discourse and views about normality and social practices. Therefore, transition is multidimensional, complex, non-linear, non-deterministic, and highly uncertain. Although energy transition is often assessed based on the speed of changes in the tangible dimension, it is a multilayered process with multiple actors.

As the transition outcome is the result of an interaction of technology, institutions, society and agents, in practice, it is difficult to predict accurately the behaviour of such a process. Relying on historical data is one way of dealing with these issues; however, as we emphasize later in this section, such analysis has its own limitations. In this section, we highlight the key features of energy transition using historical evidence, economic insights, and the literature on the social dimension of energy transition.

\subsection{Renewables have hit a critical inflection point}

Most technologies exhibit an S-shaped performance curve over their lifetime. This curve implies that, at the beginning, the performance of new technologies improves and penetrates the market very slowly but it accelerates at some point thereafter, and finally diminishes when technology becomes mature. This performance acceleration is very important during the technology maturity cycle, because it is the critical inflection point after which the speed of penetration of technology will grow at a much faster rate than before. There is evidence suggesting that wind and solar have already reached the inflection point.

\footnotetext{
${ }^{1}$ As its name suggests, the most observable element of the energy transition is the tangible aspect of energy system that embraces the energy supply chain from upstream extractive industries and systems of national conversion and supply, to enduser technologies (prime movers) and delivery infrastructure.
} 

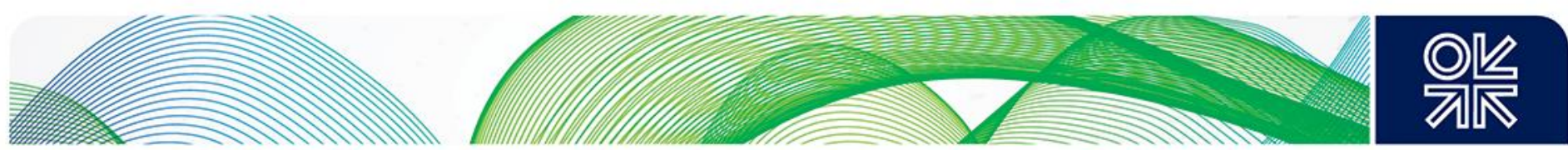

Wind powered around 2.5 per cent of total global energy needs in 2016 and solar powered 1 per cent, on an end-demand basis (deducting the efficiency losses from combustion of fossil fuels). But our conclusion from studying the 250-year history of the energy markets is that wind and solar are inflecting in a way that resembles coal in the 19th century and oil in the 20th century, and are therefore likely to be equally transformational over the 21st century. In 2011-16, we estimate that final consumption of global energy rose by $810 \mathrm{TWh}$ pa (terawatt hours per annum). Solar met $54 \mathrm{TWh}$ pa of the new demand ( 7 per cent) and wind met 105 TWh pa (13 per cent). This gave wind and solar a 20-per-cent share of the new growth in demand, up from zero prior to 2000. Figure 1 shows the longer-term history of different energy sources competing to supply new demand for energy. Coal supplied 15 per cent of new demand in 1800-30, before inflecting to 50 per cent of new demand in 1830-60 and 70 per cent of new demand in 1860-80. Oil supplied 9 per cent of new demand in 1900-20, accelerating to 17 per cent in 1920-40, and 29 per cent in 1940-80. At the same time, gas supplied 12 per cent of new demand in 1920-40, before accelerating to 30 per cent in 1940-2000.

Figure 1: Global energy supplied by source (per cent)

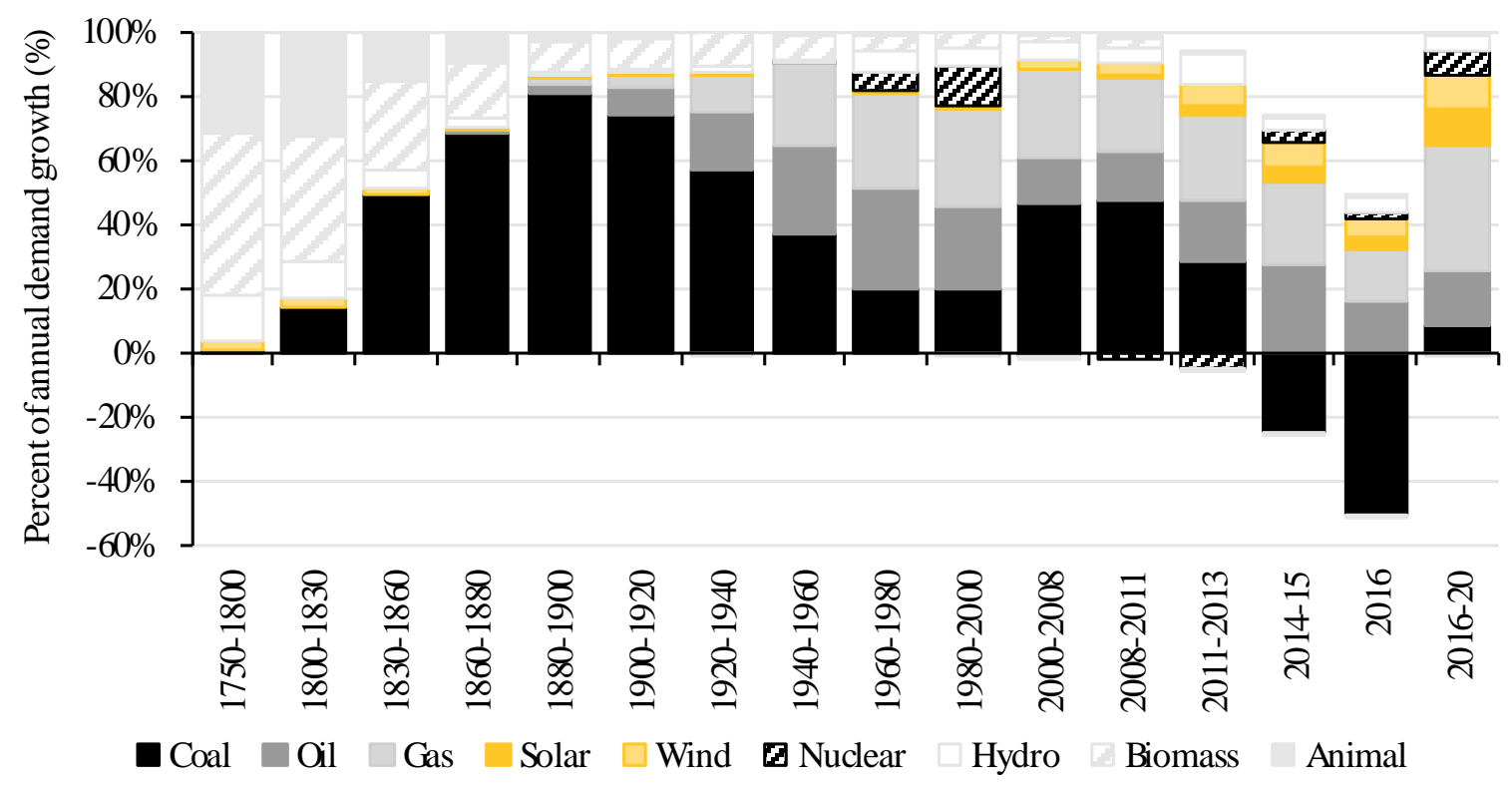

Sources: BP (2017); Carbon Dioxide Information Analysis Center; Smil (2016a, 2017); authors' estimates.

Recently, BP Energy Outlook: 2018 edition further emphasized the growing shift to renewables, noting that the pace at which renewables gain share in power generation over the Outlook is faster than any other energy source over a similar period'. Solar power projections were increased 150 per cent from 2015 estimates, due to panel cost deflation, which is expected to continue at 2 per cent pa to 2040. Hence, BP sees renewables as the fastest-growing fuel source, increasing five times, capturing around 40 per cent of new demand growth (for comparison with the data in Figure 1). Renewables would therefore be reaching 14 per cent of primary energy supplied in 2040. The trajectory of wind and solar could also be significantly higher than BP's estimates, especially if an analogy is drawn to the growth of coal in the late 19th century and oil in the 20th century. Conversely, these renewable energies must overcome intermittency and limitations in power grids to realise their full potential.

\subsection{Renewable efficiency: continuation of a long-term trend}

Penetration of renewables is not just the matter of replacement of hydrocarbons with a zero-carbon source: it also represents a material step change in efficiency. This change in efficiency has some fundamental effects on the dynamics of the energy industry. From an output perspective, and given the abundance of sunshine and wind, when a solar panel or wind turbine generates a TWh of energy, 

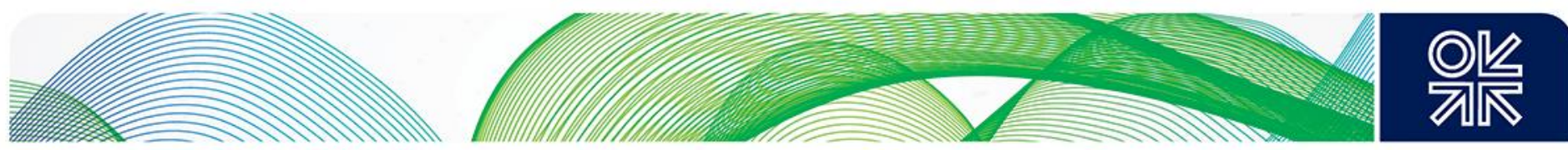

it is generated in the form of usable electricity, which is immediately available to consumers. Conversely, burn coal in power generation and only around 40 per cent of the energy content in the material can be captured as electricity. Gas is only mildly better at around 50 per cent in a combined cycle gas turbine. And, in the internal combustion engine, less than 20 per cent of the energy in gasoline is harnessed as mechanical energy. Therefore, when considered from the perspective of end demand, one of the most valuable disruptive effects of renewables is that each TWh of generated energy can displace 2.5 TWh of coal supplies or more than 5 TWh of gasoline supplies. Greater efficiency is one of the reasons Table 1 shows renewables costs to be highly competitive.

But the long-run history helps to contextualize the step change in efficiency arising from renewables: the primary efficiency of the global energy system has been steadily increasing since the early industrial revolution (Figure 2). Renewables should be seen as a continuation of the same trend. Other energy sources must continue adapting to improve their own efficiency.

Table 1: Recent costs of usable kWh of energy by source

\begin{tabular}{|c|c|c|c|c|c|}
\hline Energy Source & Cost & Average price (\$) & $\begin{array}{r}\text { Energy } \\
\text { (kwh/unit) }\end{array}$ & Efficiency & $\begin{array}{r}\text { Effective } \\
\text { energy cost } \\
(\mathrm{c} / \mathrm{kWh})\end{array}$ \\
\hline UK on-highway gasoline & Variable & $6.5 / \mathrm{gal}$ & 33 & $18 \%$ & 107 \\
\hline US on-highway gasoline & Variable & $2.6 / g a l$ & 33 & $18 \%$ & 44 \\
\hline UK retail electricity & Variable & & & & 23 \\
\hline US wholesale gasoline & Variable & $1.8 / \mathrm{gal}$ & 33 & $45 \%$ & 12 \\
\hline US retail electricity & Variable & & & & 10 \\
\hline Oil & Variable & $50.0 / \mathrm{bbl}$ & 1,700 & $45 \%$ & 6.5 \\
\hline Wind & Full & & & & 5.0 \\
\hline Asian gas & Variable & $7.0 / \mathrm{mcf}$ & 301 & $50 \%$ & 4.6 \\
\hline European gas & Variable & $7.0 / \mathrm{mcf}$ & 301 & $50 \%$ & 4.6 \\
\hline Solar & Full & & & & 3.6 \\
\hline Coal & Variable & $80.0 /$ ton & 5,815 & $40 \%$ & 3.4 \\
\hline US gas & Variable & $3.0 / \mathrm{mcf}$ & 301 & $50 \%$ & 2.0 \\
\hline World's cheapest solar tari & Full & & & & 1.8 \\
\hline
\end{tabular}

Source: Authors' estimates.

Notes: bbl = barrel; gal = gallon; mcf = thousand cubic feet.

In the past 250 years, global energy efficiency has accelerated at $0.1 \mathrm{pp}$ (percentage points) pa (Figure 2). Particularly since the oil shock of 1980 , energy efficiency has accelerated at $0.3 \mathrm{pp}$ pa. Electrification has long contributed to efficiency gains, rising from 10 per cent of global energy consumption in 1945, to one-third in 1980 and one-half today. In 1900, electric generators achieved just 5-10 per cent thermal efficiency. This rose to around $5 \mathrm{pp}$ per decade until 1960 . The best combined cycle gas turbines today are around 60 per cent efficient. Even greater efficiency gains are visible when concentrating on specific industries. In heating, pre-industrial open fires captured around 5-10 per cent of energy at best, while the best gas furnaces achieve 97 per cent thermal efficiency today. In materials, the most common metal produced on earth is steel, made from iron, whose manufacture consumes 7 per cent of the world's primary energy. Energy needed to smelt a ton of iron fell from 76 MWh (Megawatt hours) in 1750 to 15 MWh in 1900, 8 MWh in 1950 and around 4 MWh by 2010. Large blast furnaces today require 90 per cent less energy per ton of finished metal than the pig iron furnaces of pre-industrial times (Lüngen, 2013).

Vehicle efficiency has arguably lagged these other examples. Sources quote the fuel economy of the Ford Model T and other pre-war vehicles at $14-21 \mathrm{mpg}$. New passenger cars' fuel economy flatlined at $23 \mathrm{mpg}$ in the 1980s, 1990s, and early 2000s, according to the US Environmental Protection Agency (EPA). In the past decades, improvements accelerated again, to 2.5 per cent pa; around 5 per cent annual improvements are decreed by Obama-era CAFE (Corporate Average Fuel Economy) standards (EPA, 2018). 

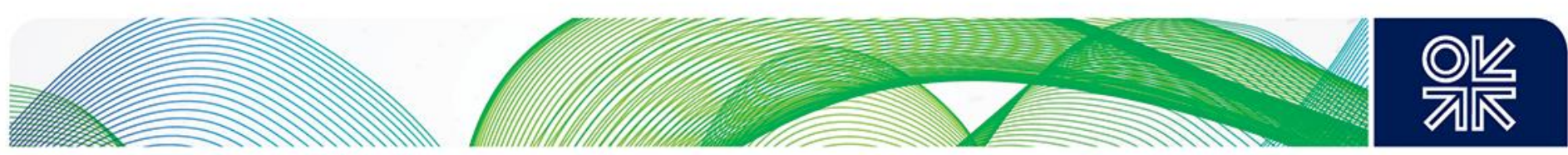

Efficiency gains have a deflationary effect on cost of energy services. In 2000, a lumen of light in Britain cost 0.01 per cent of what it did in 1500. The cost of heating, industrial power, and transportation over land all fell 90-98 per cent since 1500 (Fouquet, 2008). Real electricity prices also declined 97-98 per cent across the developed world in the 20th century (Kander, Malanima, and Warde, 2013). This is the other main reason energy producers must consistently focus on efficiency and cost control.

Figure 2: Conversion of primary energy supply into consumable energy

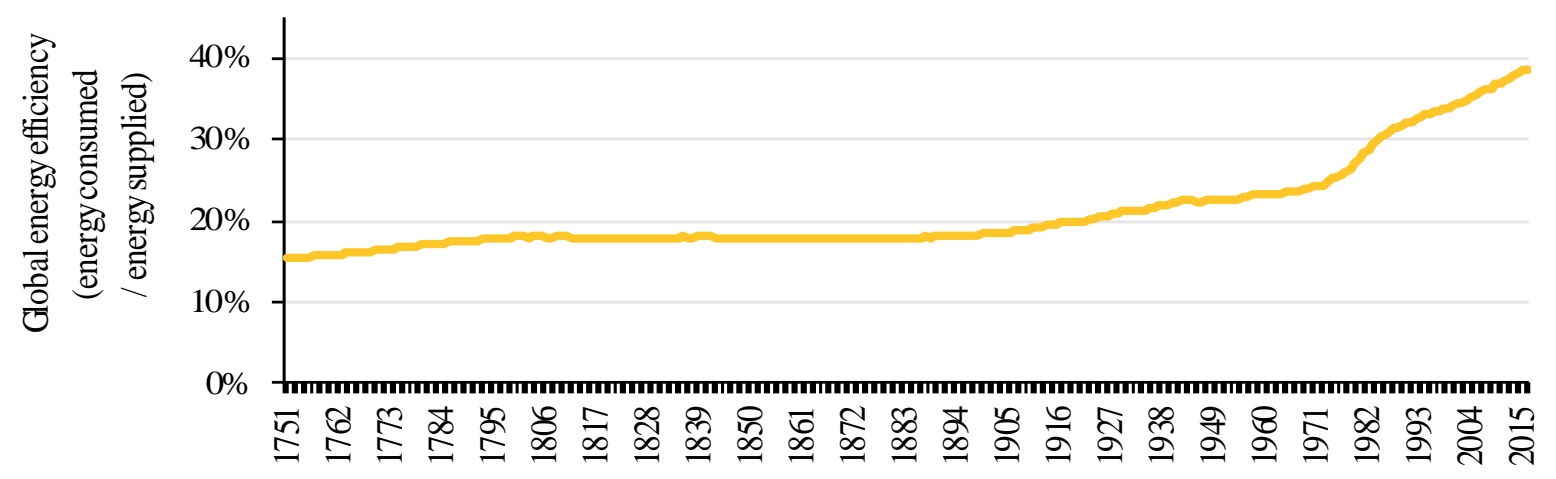

Source: Authors' estimates.

Returning to the theme of demand, more efficient, cost-deflated energy will unlock new consumption patterns. This effect is termed the 'Jevons Paradox', after the English economist who noted great increases in coal consumption when steam engines became more efficient. 'It is wholly a confusion of ideas to suppose that the economical use of fuels is equivalent to a diminished consumption. The very contrary is the truth. As a rule, new modes of economy will lead to an increase of consumption', Stanley Jevons wrote in 1865. Although the rebound effect can kick in with the rise in energy efficiency, there is also the possibility of an asymmetric response, meaning that consumers reduce their consumption when the cost of energy is high but do not necessarily increase their usage when the costs of energy services decline. There is some empirical evidence on such asymmetric response (Gately and Huntington, 2002).

\subsection{New energy sources can unlock new energy demand}

One of the key features of past energy transition has been its effect on demand. The historical data show that revolutions on the supply side of market in previous energy transitions have had an impact on the demand side. In other words, new energy sources unlocked new sources of energy demand, meaning that when new energy sources enter the global mix, energy demand growth has tended to accelerate.

British coal was initially used as a heating fuel, then in mines: first for pumping, then winding, and then ventilation. Coal's abundance, however, opened new forms of transportation. The first use was steam ships, most famously, Robert Fulton's Clermont on the Hudson River in 1807. When the Stockton and Darlington Railway opened in 1825, freight was first carried by horses. It was only four years later that Stephenson's Rocket won the Rainhill Trials, held to determine the best design for steam-powering the new Liverpool and Manchester Railway. For a full half-century after, global energy demand accelerated $1 \mathrm{pp}$ pa faster than global populations. Later, coal was the primary fuel used for electricity generation, starting in 1882 when the Edison Illuminating Company began supplying power to Pearl Street Station in Lower Manhattan. This prolonged coal's 4 per cent pa demand CAGR (compound annual growth rate) into the early 1900 s.

In the 1860 s, rock oil was originally used to displace whale oil in lighting. Abundant oil supplies, however, allowed engineers to refine the gasoline and diesel engine in the 1880s and 1890s. Mass production of the Ford Model T from 1908 increased the pace of global energy demand growth to a 

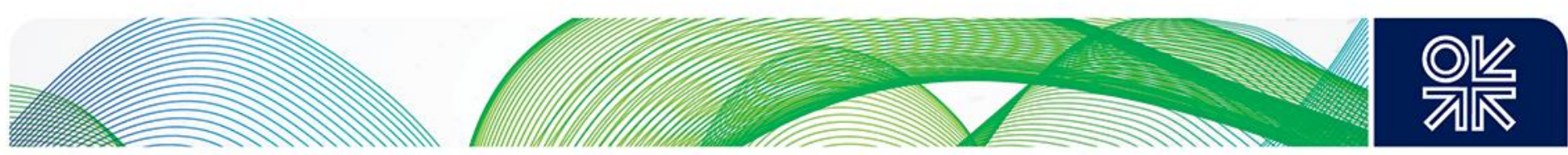

new record of 3 per cent pa prior to the First World War; and 4 per cent pa in the post-war boom from 1945 to the first oil shock in 1973.

Therefore, given the possibility of induced effects of supply side revolutions on demand side, an important question is whether the renewable energy revolution will compete for market share in a fixed global energy market? If historical trends are repeated, it is possible that new sources of energy will unlock new demand that is not currently easy to envisage (currently demand is almost stagnant in most of developed world). As one example, Bitcoin mining is estimated to consume around 42 TWh of energy this year (2018), about the same as the entirety of New Zealand (BP, 2017).

Speeding up travel by ten times, while saving time, requires a thousand times more power to overcome air resistance. Indeed, history shows the world has unlocked exponentially more powerful machinery over the past 300 years as energy supplies have become more abundant (Figure 3). Following the thread of commonly available transportation options, a horse-pulled wagon in 1890 achieved $1 \mathrm{~kW}$ (kilowatts) of output; the 1910s Ford Model T achieved $15 \mathrm{~kW}$ at full speed; a 1985 Honda Civic outputs $65 \mathrm{~kW}$; and, the most popular vehicle sold in the US last year, the Ford F-150, can output $200 \mathrm{~kW}$. Likewise, in industry, a donkey treading a Roman hourglass mill could output 300 W (watts) in 100BCE; an eight-man Dutch treadwheel output $800 \mathrm{~W}$ in around 1500; Newcomen's steam engine output 3.75 kW in 1712; Edison's Pearl Street station reached 92 kW in 1882; industrial compressors achieved 10 MW (megawatts) in 1970; and, today, the world's largest nuclear plant can output $8.2 \mathrm{GW}$ (gigawatts). Lastly, in the sphere of mass transportation, a 170-man Greek Trireme could output $20 \mathrm{~kW}$ in 500BCE, scaling up to $30 \mathrm{MW}$ at a Japanese container ship in 1960, and 60 MW for a Boeing 747 in 1970 (Smil, 2017).

New energy sources also unlocked social and industrial changes. A wealth of recent research suggests 50-year pulsations in human waves of innovation, triggered by new primary energies (Bernard et al, 2013). An age of decentralized renewable power growth might be expected to lessen the importance of large cities, and promote more dispersed settlements, linked into the economic system by greater digital connectivity and more rapid travel. If so, this trend would have very longterm implications for almost all sectors and industries, from retail footfall to land value.

An important caveat for extrapolating from the past here, however, is that the constraint of the current energy transition is greenhouse gas emissions and not energy consumption. In other words, even if new sources of energy unlock new demand, there is no guarantee that it will benefit hydrocarbon resources if such new demand for fossil fuel resources is energy based and the problem of emissions remains unresolved. Future energy demand growth will be constrained by carbon emissions; thus, it is unlikely that the new demand would lead to the same inter-fuel competition as seen in the historical transitions.

Figure 3: Power consumption rating of typical industrial, wind, and transportation exemplars

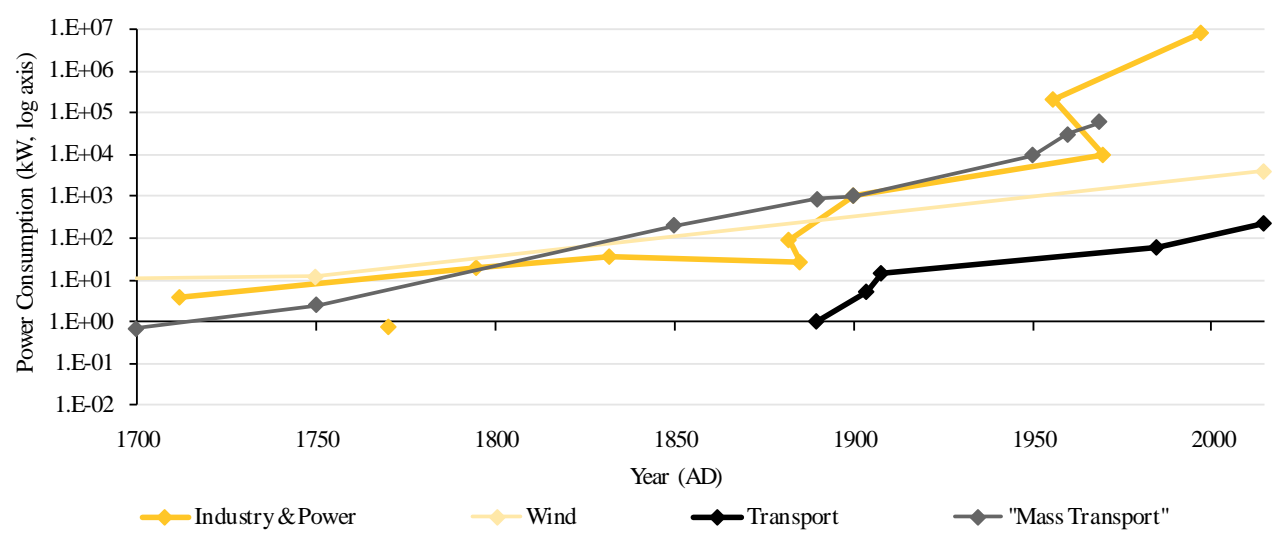

Source: Smil (2017). 

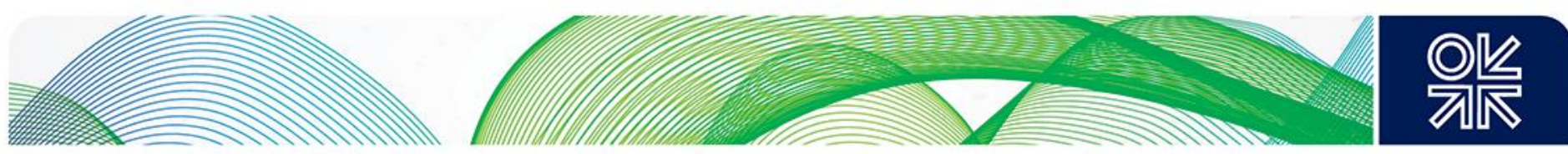

\subsection{The speed of energy transition: slow or fast?}

It is not an overstatement to say that the speed of energy transition is the most critical parameter of transition, which has serious implications for the business strategy of actors in the energy sector. Nonetheless, predicting the speed of transition with certainty, based on available information, is almost impossible mainly because of the complexity of transformation and presence of multiple layers and actors in this process. In this section we review the arguments and empirical evidence on the speed of transition and evaluate their robustness and predictive power.

\section{The view of slow transition}

The mainstream view is that energy transition is a slow process (Sovacool, 2016). This camp provides various arguments to back up this position. We summarize the main reasons in favour of slow transition as follows (Smil, 2016a,b, 2017; Fouquet, 2016; Sovacool, 2016; Sovacool and Geels, 2016):

- Historical data and evidence indicate that past energy transitions have been slow.

- The scale and complexity of energy transformation is such that it tends to create lock in and path dependency.

- The transition of the energy sector relies heavily on the availability of infrastructure, which often takes time and is very costly to build.

- New energy sources gradually improve their performance and competiveness (through learning curves and economies of scale). This will result in the slow replacement of incumbents in energy markets.

- Innovation diffusion is a lengthy process. It takes time for an innovation or new system to move from a niche to a mass market.

- There is a huge sunk cost involved in existing infrastructures of the current energy system, which creates inertia and provides an economic incentive to utilize them until they are written off. For example, for large power plants, capital costs, which are so large, play a key role in the decommissioning of plants. Generators' owners tend to keep existing assets running for as long as it is economically and technically feasible.

- As transition causes disruption, incumbents and declining industries will fight back and this delays the transformation process.

- Fast transitions rarely happen and, when they do, they are anomalies that are related to small countries or specific contexts with little scope for replicability elsewhere.

The key empirical evidence for a slow transition is past inter-fuel competition, which led to the substitution of coal for pre-industrial biomass and muscle power, and oil for coal (see Figure 4). In the 18th century, energy was supplied primarily by biomass and muscle power. Coal's market share rose from 5 per cent to 60 per cent between 1830 and 1914, peaking in the year that the First World War broke out. Oil rose from 1 per cent to 40 per cent between 1900 and 1973, peaking in the year of the first OPEC oil shock. Gas rose from 4 per cent in 1945 to 24 per cent today, while nuclear rose from zero per cent in 1954 to 2 per cent in 2000. 

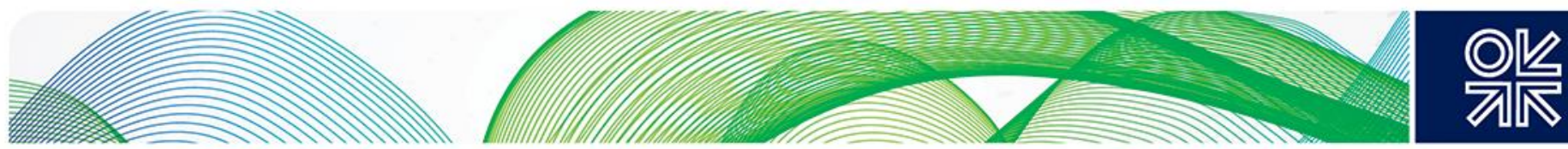

Figure 4: Global energy supplied by source

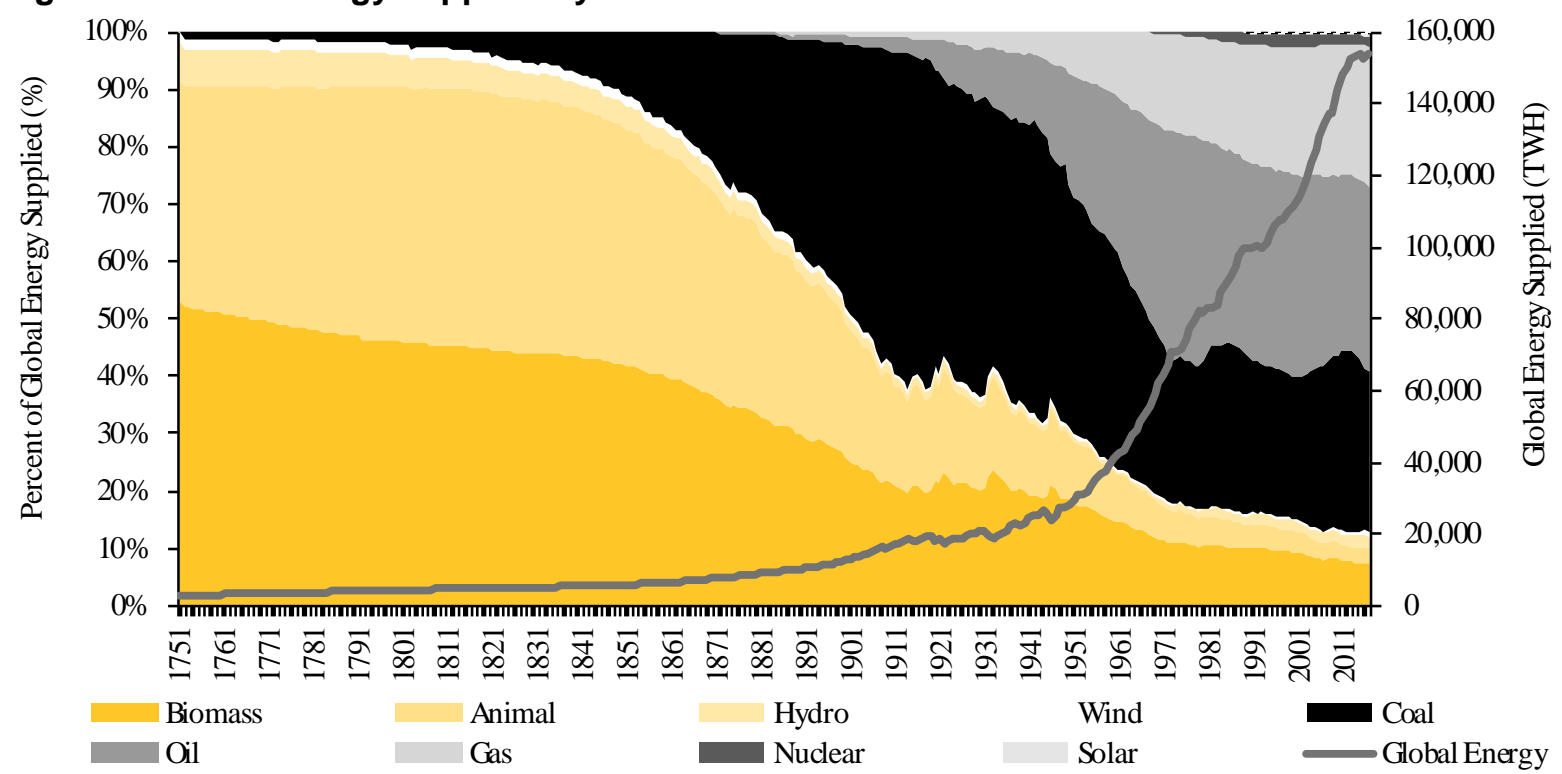

Sources: BP (2017); Carbon Dioxide Information Analysis Center; Smil (2016a, 2017); authors' estimates.

The first known use of coal for heating was in China in 100BCE. Coal mining expanded in the UK in the 1640s. The Newcomen steam engine was developed in 1712, transforming the ability to harvest coal's mechanical energy. James Watt's improved design was developed in the 1760s. But even by 1800 , with industrialization in full swing, there were only 2,000 steam engines working in Britain. For comparison, there were 6,000 water mills registered in Britain's 1086 Domesday Book survey. In the past transition, coal power changed the world, but over centuries.

Oil's share of global energy supply was only 13 per cent in 1945 at the end of the Second World War, doubling to 27 per cent by 1960 and 37 per cent by 1970. The acceleration coincided with the wave of US highway construction starting in 1956 - almost a century after Edwin Drake struck oil in Pennsylvania in 1859, let alone 16th-century descriptions of 35-metre oil wells being dug on the Absheron Peninsula, near modern-day Baku, Azerbaijan. Ford started mass-producing Model Ts in 1908. Rudolf Diesel invented his eponymous engine in 1892 (but had sold only 300 units by 1901). Karl Benz built the first practical car in 1885. So, oil also emerged over decades.

The same is true in aviation. Louis Blériot made the first English Channel flight crossing in 1909. It was not until 1957 that airlines carried more people across the Atlantic than ships. Going back even further, Roman water mills were used in the 1st century BCE, but did not become widespread for another 500 years. The first large alternating-current hydro station was build at Niagara in 1895 (37 MW). Despite the steady completion of ever-larger mega-projects - most notably China's $22.5 \mathrm{GW}$ Three Gorges Project, in 2012 - water turbines peaked at around 16 per cent of the world's electricity and around 2 per cent of total primary energy supply. Hydro did not continue expanding indefinitely to the point of dominating global energy markets. This was mainly because of water resource and environmental constraints and competing use of water for agriculture. This is probably less of an issue for wind and solar except that wind and solar farms may face public opposition when they are in the vicinity of local residences.

The past diffusion of technologies was slow even for smaller appliances, for which widespread adoption can take generations. The first home refrigerators were marketed in 1914, but became common in the US only in the 1940s, and in Europe only in the 1960s (comprising 10 per cent of domestic electricity use today). Similarly, air conditioning units were patented in 1902, but only scaled down for household use in the 1950s; while in the French census of 1954, only 10 per cent of households had a bathroom and central heating, rising to just 60 per cent by the mid-1970s (Prost, 1991). 

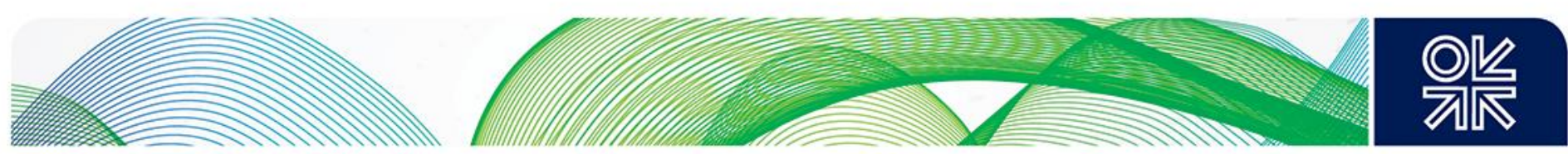

The above examples demonstrate two key features of the previous energy transitions: (a) past transitions were mainly driven by market forces, technological advances and innovation; and (b) the adoption of major energy sources occurred slowly over decades, not years.

\section{The view of fast transition}

On the other side of this debate are proponents of fast transition. The main arguments in favour of a fast transition can be summarized as follows (Fouquet, 2016; Sovacool, 2016; Sovacool and Geels, 2016):

- Comparison with the past is a biased view because the drivers of the current transition differ fundamentally from the drivers of past transitions.

- A key feature of historical transitions is that they were more opportunity-driven, whereas lowcarbon transitions are more problem-driven, which involves a collective public good (climate change). Therefore, policy plays an important role in the current transition.

- Historical transitions were more about variation (in energy mix) whereas the current transition is also about adjusting to the selection environment.

- A key feature of the current energy transition is that it is managed or incentivized (or planned and coordinated) whereas past transitions were more naturally occurring (or even accidental or circumstantial) as a result of changes in technology, price, demand, or consumer preferences.

- In a managed transition, political will and a sense of urgency in society to mitigate the adverse impacts of climate change, may lead to policies that change markets and selection environments in a rapid manner or even phase out technologies before they are written off.

- Historical evidence does not unanimously point to slow transitions. There are also examples in history of fast national-scale transitions as well as fast transitions in end-use technologies.

- In essence, the energy transition is a multilayer and multi-actor phenomenon. In such a situation, changes that are seemingly slow within one isolated layer (for example, national energy conversion and supply) can multiply when one takes a more holistic and systematic perspective.

- The current transition is not just influenced by changes in the energy sector. It draws on synergistic advances in multiple domains at once, such as 3D printing, blockchain, computing, nanotechnology, materials science, and biological and genetic engineering. Therefore, it can be accelerated in ways that have not been possible in past transitions.

- As human knowledge is a cumulative process, we can benefit from what we have learned from past transformations in order to expedite future transitions. In addition, the rates of learning and innovation in various sectors can produce technologies that previous energy systems could not, with technological characteristics that predispose them to accumulated breakthroughs that were hitherto unseen.

There is also some historical evidence that supports the argument in favour of fast transition. In terms of end-use technologies, Sovacool (2016) refers to lighting in Sweden, cook stoves in China, liquefied petroleum gas (LPG) stoves in Indonesia, and ethanol vehicles in Brazil as examples of where enduse technologies diffused at a remarkable rate.

Sweden completed the shift to efficient lighting in almost nine years (between 1991 and 2000). The National Improved Stove Program in China facilitated the penetration of improved stoves from less than one 1 per cent of the Chinese market in 1982 to more than 80 per cent by 1998 , reaching half a billion people. Indonesia completed the programme of conversion from kerosene stoves to LPG stoves to improve air quality in just three years (from 2007 to 2009). Within this period, the number of LPG stoves across the nation increased from 3 million to 43.3 million, which served almost two-thirds of Indonesia's 65 million households (or about 216 million people). Brazil created its Proálcool programme in November 1975 to increase ethanol production and substitute petroleum with ethanol in conventional vehicles; and, in 1981, only six years later, 90 per cent of all new vehicles sold in Brazil could run on ethanol. 

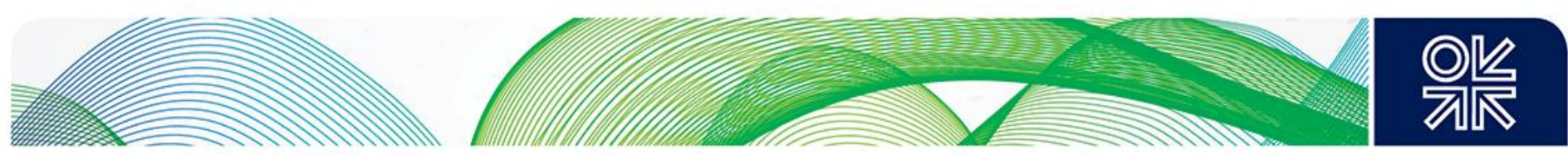

There are also examples of fast diffusion at a global scale. Indeed, cell phones are a technology that did achieve rapid penetration at world level. In 1982, the world population was around 4.6 billion but there was not a single mobile phone subscriber. In 2017, there were 7.6 billion people in the world with more than five billion mobile phone subscriptions. The smartphone, which is a more recent phenomenon, has already reached 2.4 billion users, as of 2017. Although a phone weighs tenthousand times less than a compact car, and so may not be a good basis for generalizations about other industries such as transportation, it is an indicator of the combined effects of cost reduction and consumer preference.

It is fair to say that the speed of penetration of end-use technologies such as the phone is different from supply-side resources (such as the coal and gas supply chains), because end-use technologies' penetration does not require a change in the entire energy system. Opponents of fast transition often argue that large infrastructures cannot be substituted easily, specifically at the national level. There are also examples, however, of national-scale fast transitions in energy supply that have resulted in significant changes in the infrastructure within a relatively short period of time. These are, for example, natural gas in the Netherlands, nuclear electricity in France, combined heat and power in Denmark, and coal retirements in Ontario, Canada (Sovacool, 2016).

The Netherland's discovery of the Groningen natural gas field in 1959 is an example of rapid transformation of an energy economy. In that year coal was supplying around 55 per cent of Dutch primary energy supply followed by crude oil at 43 per cent and natural gas at less than 2 per cent. In December 1965, one year after gas deliveries began from Groningen, natural gas supplied 5 per cent of the Netherland's primary energy, which rose very fast to 50 per cent by 1971 (Sovacool, 2016).

The other example is the French nuclear generation fleet. Subsequent to the oil crisis in 1973, the French government planned for a large nuclear power programme, with the aim to reduce its heavy reliance on imported oil. France built 56 reactors from 1974 to1989. As a result, nuclear power rose rapidly from 4 per cent of national electricity supply in 1970 to 10 per cent in 1978, and almost 40 per cent by 1982 (Sovacool, 2016).

The Danish energy transformation is another interesting case, which involves two sets of changes: from oil to coal as a fuel for electricity, and from individual to district heating in the heat sector. Prior to 1974 , almost all heating in Denmark was provided by fuel oil, which made country very susceptible to oil supply disruption. The government managed to achieve a remarkable transformation within five years. Indeed, from 1976 to 1981 the Danish electricity system transformed from 90 per cent oil based to 95 per cent coal based. Moreover, combined heat and power (CHP) production increased from a negligible share in 1970 to supply 61 per cent of national electricity and 77 per cent of the country's district heating in 2010 (Sovacool, 2016).

The case of Ontario presents a complete shift from a particular resource. In 2003, the government of Ontario decided to retire all coal-fired electricity generation by 2007, a goal that was accomplished with a few years delay. As a result, coal generation in Ontario declined from 25 per cent of state supply in 2003 to 15 per cent in 2008, 3 per cent in 2011, and 0 per cent in 2014 (Sovacool, 2016).

More recently, Britain is on track to become the first major economy to transition away from coal after centuries of production and consumption. In the electricity sector, the consumption of coal fell to 12 million tonnes in 2016, levels not seen since 1935 (Wilson and Staffell, 2018). This change was unprecedented; it took 14 years for power sector coal demand to increase from 12 to 28 million tonnes pa (1936 to 1950), but only one year to make the reverse transition (2015 to 2016). Also, in 2016, the total consumption of coal in the UK (in all sectors) was around 18 million tonnes, a level not seen over the past 150 years. The British case is good example of complexity of energy transition and the role of policy in expediting the process. 

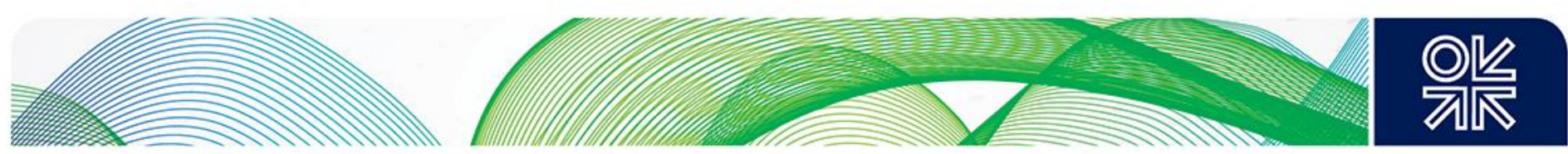

\section{Some key insights on the speed of transition}

The review of evidence and arguments for the speed of transition reveals some interesting insights:

- First, historical evidence regarding the speed of transition is inconclusive, with both cases of slow and fast transitions populating the history.

- Second, historical data about slow transition are instructive but not necessarily predictive about future transition.

- Third, the speed of transition differs across sectors and regions and has multiple layers that make it difficult to draw a concrete conclusion at the global scale.

- Fourth, policy plays a key role in the current transition at least in the short to medium term before market fully takes over.

- Fifth, today the challenge of gaining market share is amplified because the energy market is larger than ever before: 12 times on 1900 levels and 35 times on 1800.

Therefore, we argue that although transition can be fast in a specific sector or a specific country or even a specific layer of industry, the speed of grand transition (at the global level) is uncertain (it can be slow or fast). Furthermore, there is some degree of subjectivity when we talk about the time dimension of transition because it is not clear what counts as fast and what counts as slow (for example, is 30 years fast or slow?). The speed of energy transition is also susceptible to governments' change of priorities, election cycles, and political competitions.

\subsection{Implications of speed of transition for disrupted fuels}

Given the uncertainty in the speed of global energy transition we can envision two scenarios. The first scenario is one in which the grand transition happens in a slow manner (given that past radical changes in the global energy mix have tended to emerge over decades) and other energy sources have time to adapt. Historically, there are very few examples of major energy sources disappearing from the global energy mix, as seen in Figure 1. Indeed, we might think of the 19th century as the 'great age of coal' and the 20th century as the 'great age of oil'. But the world consumed twice as much wood than coal in the 19th century, and 15 per cent more coal than oil in the 20th century. In other words, coal's ascent did not mark the end of biomass, and oil's ascent did not mark the end of coal.

The ability of incumbent energy sources to adapt and to preserve market share is further illustrated by the Hirfendahl-Hirschman Index (HHI) in Figure 5. In the past half-century, what is most remarkable is how little has changed. The $\mathrm{HHI}$ is flat at 2,500. The largest change in the energy mix is natural gas gaining $10 \mathrm{pp}$ of share, at the expense of animal and biomass. But since the rise of oil and gas, no individual energy source has been able to win a dominant market share - and no major energy source has been fully eliminated. Energy sources constantly adapted to compete with one another.

\section{Figure 5: Hirfendahl-Hirschman concentration index of global energy supplies}

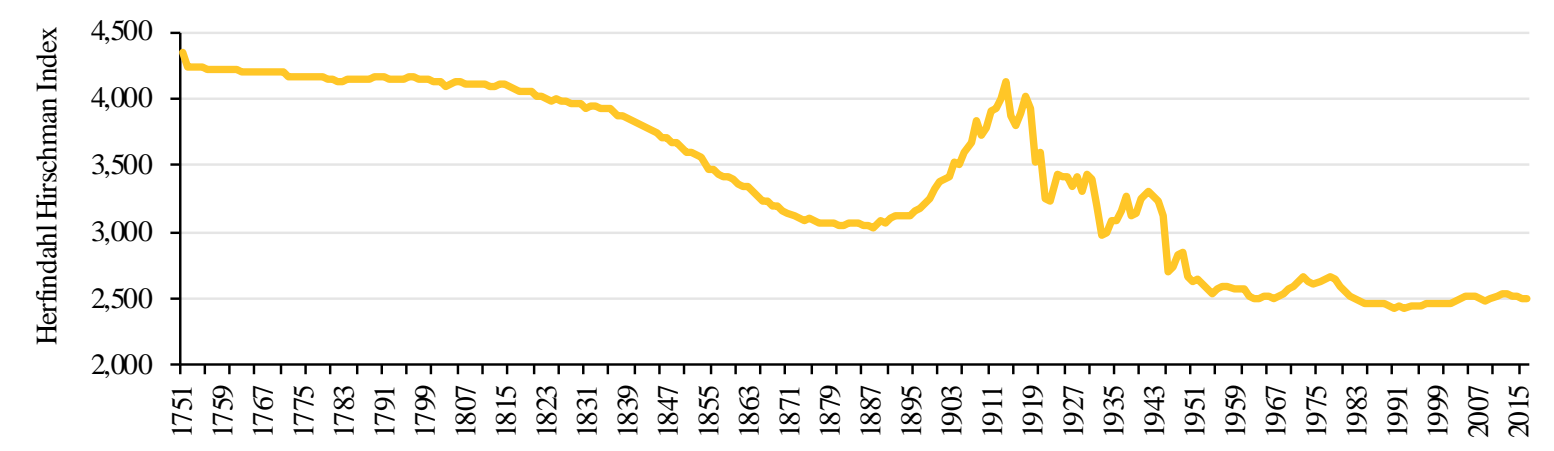

Source: BP (2017); Carbon Dioxide Information Analysis Center; Smil (2016a, 2017); authors' estimates. 

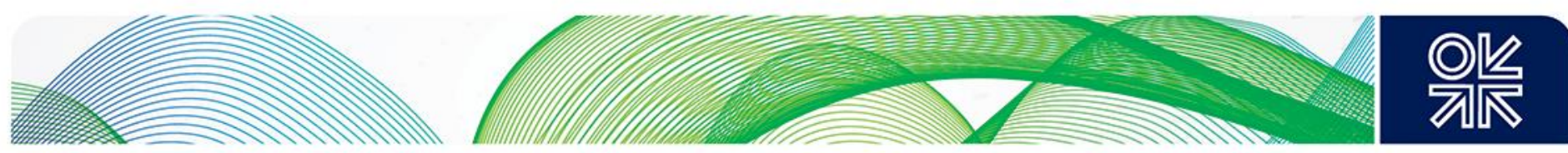

One must go back much further to find energy sources being displaced. Even in these instances, the disruption took decades or centuries, and the displaced energy source retained a pricing premium while being disrupted, rather than trading down to cost parity with its competitor. For instance, wood is inferior to coal as a fuel. The latter is around 11 times more energy dense and thus easier to transport. It also burns three times hotter, at 1,927 degrees Celsius, whereas wood burns at 600 degrees Celsius. Wood prices continued to trade at a premium for 500 years, before sufficient coal could be produced and transported to meet latent demand. Even over the course of the 20th century, the use of fuel wood and other biomass doubled to around 12,500 TWh, meeting around 12 per cent of global energy supplies in 2015 (Smil, 2010).

The second scenario is one in which the grand energy transition happens faster than expected, and perhaps in a revolutionary way, and therefore disrupts the business model of incumbents before they can adapt. Such a revolutionary disruption is not without precedence. In the book Clean Disruption of Energy and Transportation, technology advocate Tony Seba contrasts two views of New York's 5th Avenue, in 1900 and 1913. In the former, there is 'one car' in a sea of horses, and in the latter 'one horse' in a sea of cars. New York's transition from horse to car took just a dozen years. Seba argues that technology's S-curves are chronically underestimated by experts who should know better.

Furthermore, from an evolutionary perspective, historical transitions were more about developing variations (technologies) in the age of scarcity, whereas low-carbon transitions are more about adjusting the selection environments (Sovacool and Geels, 2016) in the age of abundance (via policies, regulations, and incentives that shape markets) and this affects the balance of demand and supply. Under energy scarcity in a world of increasing demand, it is possible to have a partial and slow substitution of incumbents, where incumbents even retain a pricing premium and satisfy the marginal demand in presence of a new source of energy, which is cheaper and has more calorific content (the case of wood versus coal, for example). However, things can be completely different when there is supply abundance and demand is not growing. It is possible that a new source of energy completely displaces the incumbent. In such a world, the incumbents cannot retain a pricing premium if it is going to have a market share.

\section{Implications for the strategy of oil companies and oil-exporting countries: the role of renewables}

Oil companies and oil-exporting countries cannot afford to ignore the transition of the energy sector, which can disrupt their business model and erode their revenue base. For this, they need to understand what aspects of energy transition affect their business activities. Among the multiple dimensions of the energy transition, its speed is of paramount importance for the business strategy of oil-sector actors because of its effect on the long-term demand for oil. Despite the speedy transformation of the energy sector in some regions such the EU, the speed of transition at global scale is uncertain and this further induces uncertainty in the long-term demand for petroleum resources (for example, it is not clear when peak oil demand will occur; the various demand projections are highly sensitive to underlying assumptions such as population growth, economic growth, efficiency gains, and carbon tax, among other factors). On top of that, it is difficult to define what the endgame is, which technology wins, and how the final mix of energy will look. It is quite likely that the outcome of the transition will be different across regions. Faced with these high uncertainties, the key question is: how can oil-exporting countries and oil companies adapt their business models to the transition period?

Traditionally, investment in the oil and gas sectors (and perhaps investment in the entire energy sector) has had three key features: (a) investment in hydrocarbon assets is mostly sunk and thus irreversible; (b) there is some degree of uncertainty over the reward from investment and therefore the best a decision maker could do is to assess probabilities of different outcomes that can lead to 

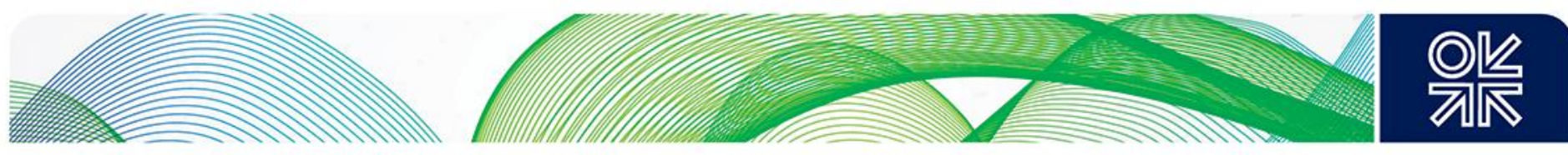

higher or a lower profit from the investment; and (c) possibility of delay meaning that the decision maker could wait until he or she obtains more information about the future. During the transition, however, the situation is even more complex as wrong assumptions about uncertainties can lead to misallocation of capital and write-offs. Worse, underinvestment in conventional energy could yield shortages, underpinning shortages of light, heat, power, and mobility - the mainstays of modern civilization. Conversely, a wait-and-watch strategy by postponing investment decisions can create a window of opportunity for competitors. The other side of the coin is that too early investment also limits future options and can lock the company into a suboptimized investment decision. Given the range of uncertainties surrounding the transformation of the energy sector, oil companies and exporting countries should consider multiple variables at once and form strategies that are resilient in most possible outcomes.

\subsection{Adaptation strategy for international oil companies and the role of renewables}

Until this decade, the business strategy of oil and gas companies was straightforward: replace or grow reserves, refine and sell products in an increasing market. As oil demand prospects have become more uncertain and traditional energy sources face disruption, oil companies need a different approach. The alternative approach, however, is not straightforward. First, there is no one-size-fits-all solution. Oil companies have had a different path and risk attitude, different endowments, have operated in different geographies, and have different types of expertise (some, for example, are more experienced in offshore operation than others).

Second, the successful response of oil companies to energy transition is beyond the question of integrating or not integrating renewables in their business model. The natural hedge of industry against the decline in oil demand growth might be to increase the share of gas in their portfolios, which still has room for growth, at the least in the medium term (in fact, of seven new projects being brought onstream by BP in recent years, six involve gas rather than oil; others, such as Shell and Total, are making a similar shift) ${ }^{2}$. The support for a functioning carbon tax by some oil companies can also be seen in this light, because it benefits natural gas at the expense of coal. In the long run, however, gas use in power generation will struggle to maintain market share - although gas might retain a competitive role in high-value heating. In effect, oil companies need to evaluate which part of their business model is at risk with energy transition and in what time frame. Successful adaptation strategies in the past have included unlocking new sources of demand, improving efficiency, and deflating costs. Some of these lessons are applied in Table 2.

\footnotetext{
${ }^{2}$ Therefore, we do not pretend to offer a comprehensive strategy for oil companies in response to energy transition; instead, a way of thinking about the issue.
} 

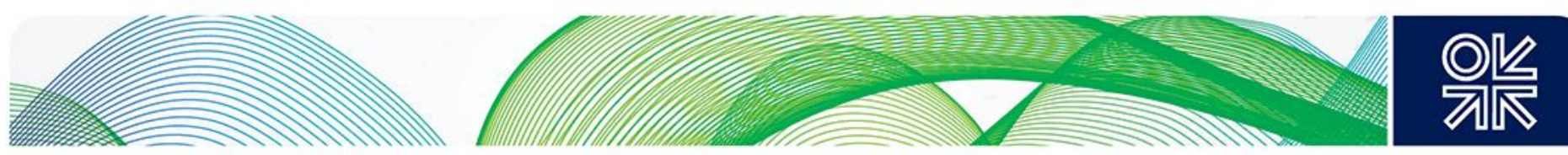

Table 2: Very long-run outlook and adaptation strategies for oil and gas

\begin{tabular}{|c|c|c|c|}
\hline & Outlook & Rationale & Preferred adaptation strategy \\
\hline $\begin{array}{l}\text { LNG for } \\
\text { power }\end{array}$ & Most negative & $\begin{array}{l}\text { Maintaining } \$ 7 / \mathrm{mcf} \text { LNG equates to } \\
4.6 \mathrm{c} / \mathrm{kWh} \text { at existing import facilities; } \\
10 \mathrm{c} / \mathrm{kWh} \text { to grow market share }\end{array}$ & $\begin{array}{l}\text { Deflation. } \$ 4-5 / \text { mcf long-run LNG is } \\
\text { required to compete effectively with } \\
\text { renewables }\end{array}$ \\
\hline $\begin{array}{l}\text { Oil for } \\
\text { power }\end{array}$ & Negative & $\begin{array}{l}\$ 50 \text { oil equates to } 6.5 \mathrm{c} / \mathrm{kWh} \text { when } \\
\text { burned in power generation (c10\% } \\
\text { higher if burning diesel) }\end{array}$ & $\begin{array}{l}\text { Lose market share. Defending } \\
\text { current c5Mbpd demand requires } \\
\text { c } \$ 30-40 / \mathrm{bbl} \text { oil }\end{array}$ \\
\hline $\begin{array}{l}\text { Oil for } \\
\text { transportation }\end{array}$ & Mixed & $\begin{array}{l}\text { Low efficiency of internal } \\
\text { combustion engine makes oil } \\
\text { uncompetitive. But rate of } \\
\text { displacement is limited by pace of } \\
\text { electric vehicles (seen at 150-500m } \\
\text { by } 2040 \text {, out of a vehicle parc } \\
\text { approaching } 2 \text { billion) }\end{array}$ & $\begin{array}{l}\text { Create new demand in long- } \\
\text { distance, high-velocity, high-bulk } \\
\text { travel that is mechanically better } \\
\text { suited to oil's } 10 x \text { higher energy } \\
\text { density than batteries (e.g., super- } \\
\text { sonic jets, flying cars) }\end{array}$ \\
\hline $\begin{array}{l}\text { Gas for } \\
\text { heating }\end{array}$ & Positive & $\begin{array}{l}\text { At } \$ 7 / \text { mcf gas, efficient gas boilers } \\
\text { can achieve } 3-4 \mathrm{c} / \mathrm{kWh} \text { (at retail gas } \\
\text { prices), which is } 3 \times \text { better than } \\
\text { electrical heating }\end{array}$ & $\begin{array}{l}\text { Vertical integration. Majors may } \\
\text { wish to go downstream in gas value } \\
\text { chains }\end{array}$ \\
\hline $\begin{array}{l}\text { Oil for } \\
\text { materials }\end{array}$ & Most positive & $\begin{array}{l}\text { Materials are not prone to } \\
\text { substitution by new energy, and are } \\
\text { themselves the disruptors (e.g., } \\
\text { thermoplastic composite carbon } \\
\text { fibre is } 10 \times \text { lighter than similar- } \\
\text { strenath steel) }\end{array}$ & $\begin{array}{l}\text { Create new demand, in high-value } \\
\text { modern materials }\end{array}$ \\
\hline
\end{tabular}

Source: Compiled by the authors.

A relevant question is whether oil companies' core business skills can be translated into the renewables business. It is not so difficult to see why oil companies are reluctant to undertake such a move. First, oil companies are used to invest in high-return upstream projects whereas return to investment in renewables is modest. Oil companies compete on efficiency and economics whereas renewables are a regulated industry. The higher return of upstream and familiarity with industry often wins over the risk and modest return of renewable investment. Second, the success of the renewables industry depends on the availability of subsidies, and oil companies are often reluctant to develop a complete business strategy around subsidies for various reasons (for example, dependability on policy support and unpopularity of subsidies for oil companies). What complicates the issue is that oil companies' past moves into the renewables industry have not been always successful. BP invested $\$ 8.3$ billion in wind and renewable assets in 2005-13. It failed to find a buyer for its $1.6 \mathrm{GW}$ of US wind capacity in 2013. The replacement cost at today's wind prices is estimated at around $\$ 2.3$ billion.

Shell's CEO, Ben van Beurden, has resisted being 'rushed' into renewables. During a press interview in October 2017, he said, 'We were among the first of the big international oil companies to get into solar and we found out we could not make any money out of it'. In January 2018, BP's CEO, Bob Dudley, acknowledged the need for a different model from its prior renewables projects. He mentioned:

On the solar point, you'll recall back in the 2000s, the company made big bets [on renewables] ... In fact, around 2000, BP had the third largest solar company in the world behind Sharp and Hitachi. Gosh, has the world changed. So, we manufactured it. We started in the US. We moved to Spain, we moved to India, we moved to China. Solar cells became commoditised. And panels. That's not what we're doing today. We learned that lesson really well. 

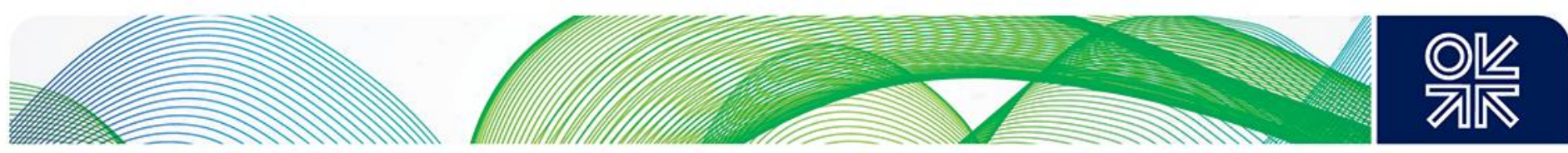

Despite these drawbacks, oil companies should not see their options as a choice between either renewable or hydrocarbon investment, but rather a choice between static efficiency (focusing on maximizing the return from their current hydrocarbon assets) and dynamic efficiency (positioning in the transition for long-term survival). We argue that neither a wait-and-watch strategy nor a hasty move to renewables is a good way of positioning for energy transition, because both approaches are risky from a business perspective. Instead we suggest gradual 'business model extension' as part of a comprehensive adaptation strategy. The business model extension involves changes in the investment, operation, research and development, and coalition decisions of oil companies with a special view to future technologies. For a successful move, oil companies need to reassess their existing portfolio across the entire value chain and consider opportunities in most competitive and valuable assets, both from hydrocarbon and low-carbon resources. The operating model of these companies also needs to become more compatible and agile given the continuing change in the energy sector. The business model extension differs from the shifting strategy in that it balances the short-term revenue maximization with long-term business disruption risk. For example, if, for any reason, it turns out that the oil company has made incorrect assumptions about the speed of transition, winning technologies, and future energy mix, it will only affect part of their business model. Therefore, an oil company with an extended business model is unlikely to face a total business disruption even under a worst-case scenario.

One of the key elements in the extended business model should be to integrate renewables into hydrocarbon projects. For instance, the oil majors have a presence in nine countries presented in Table 3, where domestic gas prices average just $\$ 3 / \mathrm{mcf}$, while export infrastructure to access higherpriced markets is around 35 per cent underutilized. The average country in this list receives 2,000 $\mathrm{kwH} / \mathrm{m}^{2} /$ year of solar irradiance, making solar a viable option for domestic power generation, which in turn 'liberates' gas supplies that are currently being consumed domestically for export. It also makes particularly good sense to house solar investments in 'sunnier' countries that receive two to three times more insolation than Northern Europe. All else being equal, this allows solar projects to earn their cost of capital at a lower tariff.

Table 3: Countries where solar projects can liberate gas volumes

\begin{tabular}{|c|c|c|c|c|c|c|c|}
\hline Country & $\begin{array}{r}\text { Solar } \\
\text { irradiance } \\
(\mathrm{kWh} / \mathrm{m} 2 / \mathrm{yr}) \\
\end{array}$ & $\begin{array}{r}\text { Gas } \\
\text { production } \\
(\mathrm{Bcm}) \\
\end{array}$ & $\begin{array}{r}\text { Gas } \\
\text { demand } \\
(\mathrm{Bcm}) \\
\end{array}$ & $\begin{array}{r}\text { Gas export } \\
\text { capacity } \\
(\mathrm{Bcm} \text { pa) } \\
\end{array}$ & $\begin{array}{r}\text { Recent } \\
\text { export } \\
\text { utilisation } \\
\end{array}$ & $\begin{array}{r}\text { Domestic } \\
\text { gas price } \\
(\$ / \mathrm{mcf}) \\
\end{array}$ & Companies \\
\hline Algeria & 2,200 & 91.3 & 40.0 & 59.0 & $56 \%$ & 0.5 & BP, Statoil \\
\hline Egypt & 2,200 & 41.8 & 51.3 & 16.6 & $0 \%$ & c6 & Eni, BP, Shell \\
\hline UAE & 2,400 & 61.9 & 76.6 & 7.6 & $97 \%$ & 1.1 & Shell \\
\hline Oman & 2,400 & 35.4 & 40 & 14.8 & $68 \%$ & c6 & $\mathrm{BP}$ \\
\hline Australia & 2,300 & 91.2 & 41.1 & 88.0 & $97 \%$ & 4.2 & Majors \\
\hline Trinidad & 1,800 & 34.5 & 19.1 & 20.7 & $81 \%$ & 2 & BP, Shell \\
\hline Indonesia & 1,500 & 69.7 & 37.7 & 56.6 & $37 \%$ & 5 & Majors \\
\hline Peru & 1,600 & 14.0 & 7.9 & 6.0 & $82 \%$ & 1.8 & $\mathrm{BP}$ \\
\hline Yemen & 2,450 & 0.7 & n.m. & 9.1 & $43 \%$ & 7.1 & TOTAL \\
\hline Total & 2,094 & 440.5 & 314 & 278 & $65 \%$ & 3.0 & \\
\hline
\end{tabular}

Source: Authors' own calculations based on company data.

Notes: Bcm = billion cubic metres.

However, faced with increased pressures from shareholders and in anticipation of a speedier transition, integrating renewables into existing projects may be seen by many as companies not doing enough and, therefore, in the upstream, oil companies may need to extend their portfolio outside fossil fuels, even though it is seemingly far from their core business. Indeed, it is recognized that there 

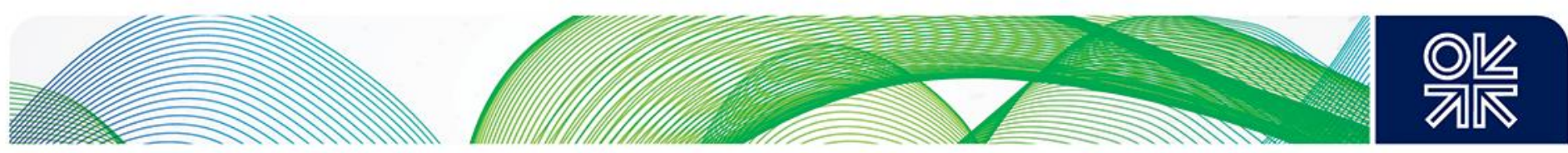

is a risk involved in moving beyond the core business; however, it is often argued that this risk needs to be weighed against the risk of eventual disruption of the business model.

In practice, the oil majors' most recent solution has been to gain a foothold in renewables through bolt-on acquisitions. For instance, in April, Total agreed to purchase Direct Energie for $€ 1.9$ billion in cash, to gain access to a pre-existing pipeline of $550 \mathrm{MW}$ of renewable capacity, plus a larger pipeline of 2 GW. This follows BP's $\$ 200$ million acquisition of a 43-per-cent stake in LightSource in 2017, alongside plans to quadruple its solar capacity to $8 \mathrm{GW}$. In December 2017, Shell agreed to acquire the UK's First Utility, also moving its business further downstream into the power sector - although this bolt-on (likely to be around $£ 200$ million) was shy of a potential bid for Equis Energy, Asia's largest renewables firm, at $11 \mathrm{GW}$, which ultimately sold for $\$ 3.7$ billion to GIP.

While underlying project economics appear sound, the risk of rapid renewables growth - organic or via multiple bolt-on acquisitions - is that patience is required by shareholders. For instance, on modelling Statoil's seven largest renewables projects, we conclude that while the overall IRR (internal rate of return) will exceed a passable 8 per cent hurdle rate, the overall portfolio will not turn free cash positive until the late 2020s; while it will be in the early 2030s that return on capital employed hits 10 per cent in the continually growing renewables portfolio (see Figure 6).

Figure 6: Estimated free cash flow profile of seven Statoil renewables projects

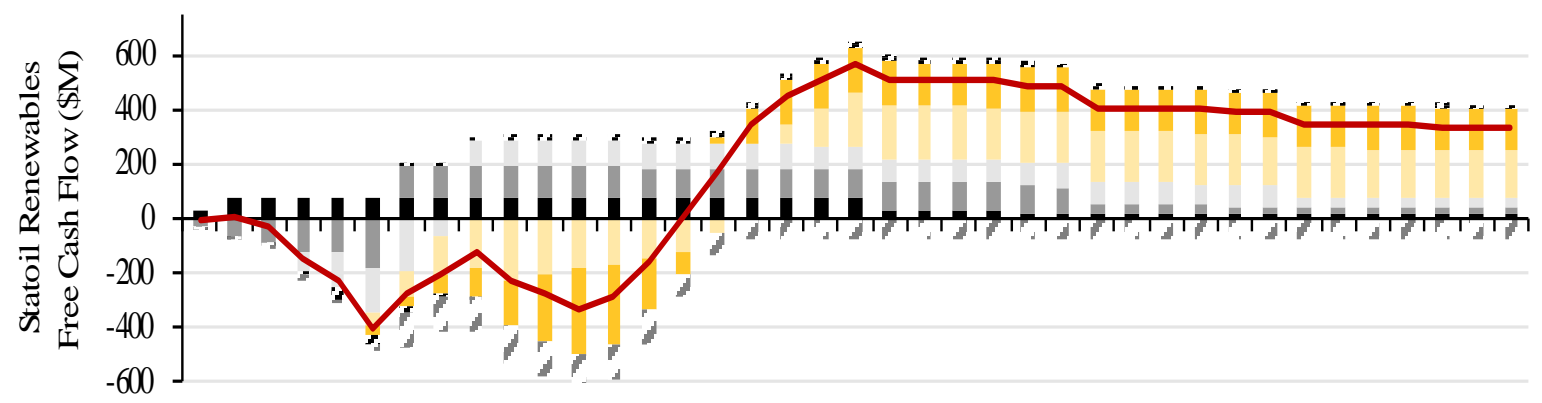

20122014201620182020202220242026202820302032203420362038204020422044204620482050

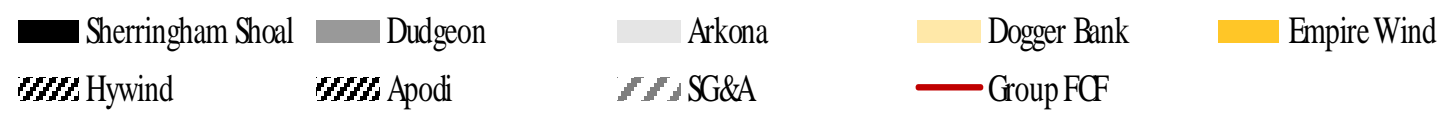

Source: Authors' own calculations based on company data.

\subsection{Adaptation strategy for oil-exporting countries and the role of renewables}

The countries that are dependent on oil and gas production for government revenue are also highly vulnerable to changes in the energy landscape. There are two important differences between major oil companies and oil-exporting countries in relation to energy transition. While the key issue for oil companies is disruption of existing business models, the main challenge for oil-exporting countries, in addition to loss of revenues, which is essential for the functioning of their economies, is the ability to monetize their large reserve base. This is mainly because the proved reserved to production ratio of international oil companies is typically around eight to ten years, whereas this number is several decades, beyond all peak oil demand forecasts, for some of the resource rich countries (for example, it is more than 63 years for Saudi Arabia with around 90 per cent dependence of government budget on oil revenues). This makes the inability to monetize the reserve base a serious risk in these countries.

The second important difference is that, for oil-exporting countries, there is no conflict between static and dynamic efficiency when it comes to positioning for the energy transition. Indeed, investment in renewables could help further boost their short-term revenues as it frees up their hydrocarbon resources for export (as long as international prices are above the break-even price). Oil-exporting countries have unique characteristics that make the rationale of investment in renewables for them 

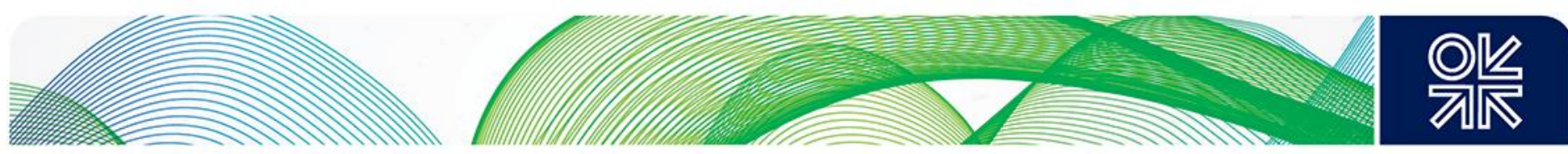

quite compelling. These countries have rising energy demand and are at a stage of development where economic growth is tied up with energy consumption. The rise in energy demand is expected to strain the export capability of these countries. Indeed some of them, such as Kuwait and the UAE, are already net importers of natural gas.

The economics of renewables in exporting countries depends on the opportunity cost of domestic oil and gas consumption, which is reflected in international price of hydrocarbon resources. According to the Energy Information Administration (EIA) (2016), generating $1 \mathrm{MWh}$ of electricity requires 1.73 barrels of oil or $10.11 \mathrm{mcf}$ of natural gas. The record low auction prices for solar photovoltaics (PV) in Dubai, Mexico, Peru, Chile, Abu Dhabi, and Saudi Arabia have shown that, under the right circumstances, an LCOE (levelized cost of electricity) of $\$ 0.03 / \mathrm{kWh}$ for solar is achievable (IRENA, 2018). IRENA (2018) also estimates the global average cost of solar PV to be around $\$ 0.06 / \mathrm{kWh}$. If the lower band is considered (which is closer to costs of solar at the region), the break-even prices of oil and gas would be $\$ 17.34 / \mathrm{bbl}$ and $\$ 2.96 / \mathrm{mcf}$ respectively, which are well below international prices. If we consider the global average costs of solar instead (which is pretty much conservative for the region), the break-even prices will increase to $\$ 34.68 / \mathrm{bbl}$ and $\$ 5.93 / \mathrm{mcf}$, which is still below the international price for oil but slightly higher than the average price for natural gas. Even if we add the costs of dealing with solar intermittency (at around $\$ 5 / \mathrm{MWh}$ ) to these numbers, the economics of renewables is still winning over traditional resources in these countries.

The economics of renewables will be boosted if we account for the gain that these countries will make from liberated oil and gas. Algeria is a good example with its underutilized gas export capacity, a miniscule $\$ 0.5 / \mathrm{mcf}$ domestic gas price, and no shortage of land in the Sahara. Here, insolation can reach $2,400 \mathrm{kWh} / \mathrm{m}^{2} /$ year. If the country develops solar to meet its power needs, it can liberate gas to direct down existing pipeline infrastructure towards high-value European markets. The economics of such a project are modelled in Table 4, taking the example of a $100 \mathrm{MW}$ investment in Algerian solar. Cost would be expected at around $\$ 140$ million. The base NPV (net present value) on power generation is zero or, in other words, the project earns its cost of capital. However, the overall NPV is uplifted to $\$ 40$ million, after adding in the value of liberated gas.

Table 4: Table of assumptions for solar investment that also liberates marketing gas

\begin{tabular}{|c|c|c|c|}
\hline Assumptions and outputs & Value & Unit & Source \\
\hline Plant size & 100 & MW & Assumption \\
\hline Solar cost & 1.4 & $\$ \mathrm{~m} / \mathrm{MW}$ & Eni guidance \\
\hline Up-front cost & 143 & $\$ m$ & Calculated \\
\hline Solar generation & 2,000 & MWH/MW/year & BP Stat Review \\
\hline Solar tariff & 5 & $\mathrm{c} / \mathrm{kWh}$ & Assumption \\
\hline Gas per MWH & 8 & $\mathrm{mcf} / \mathrm{MWh}$ & Power model \\
\hline Domestic gas price & 0.5 & $\$ / \mathrm{mcf}$ & Press reports \\
\hline European gas price & 5.5 & $\$ / \mathrm{mcf}$ & Assumption \\
\hline Transportation cost & 0.5 & $\$ / \mathrm{mcf}$ & Statoil guidance \\
\hline Fiscal take & $50 \%$ & $\%$ & Assumption \\
\hline Gas uplift & 2.25 & $\$ / \mathrm{mcf}$ & Calculated \\
\hline $\mathrm{NPV}(\$ \mathrm{~m})$ & 40 & $\$ m$ & Calculated \\
\hline $\operatorname{IRR}(\%)$ & $9 \%$ & $\%$ & Calculated \\
\hline
\end{tabular}

Source: Authors' own calculations.

For oil exporters such as those in the Middle East, which are highly reliant on oil revenues, investment in renewables addresses, to some extent, the government's short-run revenue maximization objective 

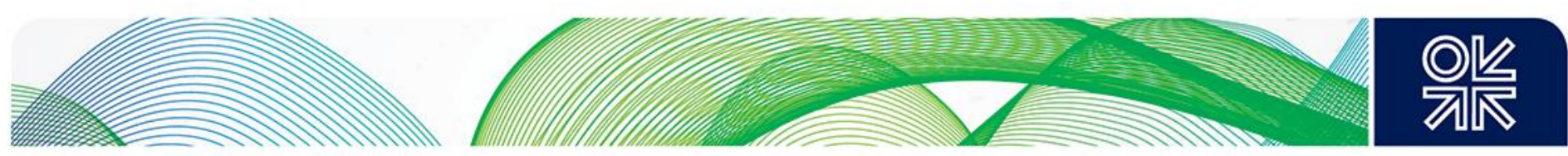

by freeing exports of hydrocarbons, but does not guarantee their long-term sustainability. In the long run, diversification of their economies remains the main adaptation strategy that these countries need to pursue. Renewables may replace hydrocarbon resources in the domestic energy mix, but not in the government budget, because investment in renewables does not generate the high returns that the oil and gas industry does. Furthermore, while the renewable energy industry is part of the diversification strategy, it alone cannot deliver the real needs of these economies, such as job creation and welfare improvements. Thus, during the transition, the oil and gas sector will continue to play a key role in these economies, generating the rents needed to expand parts of the productive economy, including manufacturing industries, agriculture, and the service sector (with a specific view to those sectors in which they have comparative advantage), in order to increase the non-oil portion of gross domestic product and, consequently, diversify the sources of governments' income. In fact, the oil and gas sector may play its part in the diversification drive through building new industries and fostering backward and forward linkages. This is a flexible strategy that maximizes the benefit from rentgenerating capital (that is, oil and gas reserves) and, at the same time, positions the country for an era that could see oil demand flatline or decline. During the transition period, export rents will initially constitute the bulk of the governments' revenues but will decline if diversification progresses as planned.

However, achieving economic diversification is easier said than done, because this entails extensive changes in the economy with implications for citizens' welfare and distribution of national income. For example, oil countries need to carry out painful fiscal reforms that will lead to the reduction or removal of subsidies (including underpriced energy careers) and the introduction of taxes, such as income and value added tax. These issues are inherently complex given the rigidity of existing political structures, institutions, and the implicit social contract through which lack of political participation is compensated for by distribution of hydrocarbon rents. This is why gradual and small-scale reforms combined with mitigation measures can be implemented, but one should not expect speedy transformations of oilexporting economies.

Also, there is a probability (which is not trivial) that these countries could fail in their goal of achieving a diversified economy. This, in turn, will impact the speed of the global energy transition. In other words, the global energy transition will not only shape the political and economic outcomes in oilexporting countries, but the transition in the major oil exporters will also shape the global energy transition. It is a two-way street. The feedback effect from exporting countries is relevant even if these countries succeed in expanding their productive economy, or the global oil market shifts from the current scarcity-oriented model to a marginal-cost-based market in which hydrocarbons cannot retain a premium pricing. For instance, if these countries succeed in their diversification objectives, they may engage in a more aggressive reserve monetization strategy, which will result in lower oil prices and large changes in relative prices of fuels, affecting the speed of transition unless these changes in relative prices are adjusted through carbon taxes, which open new sets of issues related to international coordination and distribution. On the other hand, if the transition does not go smoothly and does result in many output disruptions and more volatile oil prices, this would in turn affect the energy transition process. Such feedbacks add other layers of uncertainty to the already complex issue of the current energy transition.

\section{Conclusion}

The global energy industry verges on its next energy transition. The 21 st century will be characterized by a rising share of cost-competitive renewable technologies, and a move away from carbon-intensive fuels. The critical uncertainty is the pace of the transition.

The historical precedents exacerbate the uncertainty. Both 'fast transitions' and 'slow transitions' have occurred previously. In addition, new and unimaginable demand-side technologies have tended to emerge alongside prior energy transitions. The uncertainty cannot be resolved, only acknowledged. 

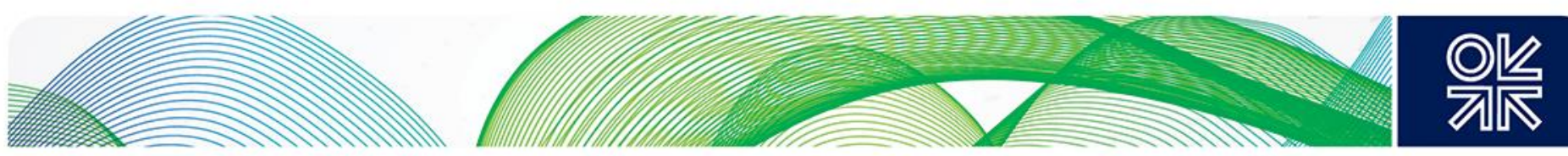

Yet, the consequences of miscalculating the pace of transition, in either direction, are dire. Scaling away from fossil fuels too quickly into alternative energy, in the presence of these uncertainties, can lead to asset write-off and loss for investors. Transition too slowly, however, and incumbents may be left with stranded assets and excluded from the benefits of the energy revolution. This is a delicate trade-off that the oil companies and oil-exporting countries need to balance.

In the face of uncertainty, we have advocated that oil- and gas-producing companies and countries should seek resilient strategies. For the oil majors, this includes gradual investment in a portfolio of proven renewable energy technologies that complement their pre-existing value chains. Transition of these businesses will require patience from investors. For oil-producing economies, policy should promote renewables investment, particularly where it liberates domestic oil and gas consumption for international export. 

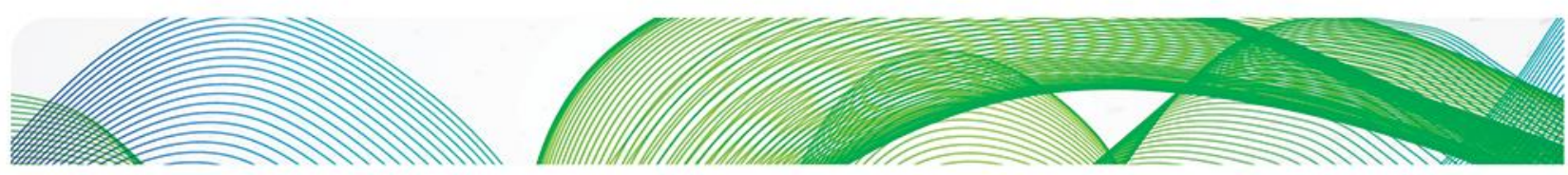

\section{References}

BP (2017). BP Statistical Review of World Energy,

www.bp.com/content/dam/bp/en/corporate/pdf/energy-economics/statistical-review-2017/bpstatistical-review-of-world-energy-2017-full-report.pdf

BP (2018). BP Energy Outlook: 2018 edition, www.bp.com/content/dam/bp/en/corporate/pdf/energyeconomics/energy-outlook/bp-energy-outlook-2018.pdf

Bernard, L. et al. (2013). 'Time scales and mechanisms of economic cycles: a review of theories of long waves', Political Economy Research Institute Working Paper No. 337, 1-21, University of Massachusetts, Amherst, MA.

Carbon Dioxide Information Analysis Center (2017), http://cdiac.ess-dive.Ibl.gov

Energy Information Administration (EIA) (2016). 'How much coal, natural gas, or petroleum is used to generate a kilowatthour of electricity?', www.eia.gov/tools/faqs/faq.cfm?id=667\&t=6 [last retrieved 09/06/2016].

Environmental Protection Agency (EPA) (2018). Highlights of $\mathrm{CO}_{2}$ and Fuel Economy Trends, www.epa.gov/fuel-economy-trends/highlights-co2-and-fuel-economy-trends

Fouquet, R. (2008). Heat, Power and Light: Revolutions in Energy Services, London: Edward Elgar Publishing.

Fouquet, R. (2016). 'Historical energy transitions: Speed, prices and system transformation', Energy Research \& Social Science, 13 (2016), 202-15.

Gately, D. and Huntington, H.G. (2002). 'The Asymmetric Effects of Changes in Price and Income on Energy and Oil Demand', Energy Journal 23 (1), 19-55.

International Energy Agency (IEA) (2017). World Energy Outlook, https://webstore.iea.org/worldenergy-outlook-2017

International Renewable Energy Agency (IRENA) (2018). Renewable Power Generation Costs in 2017, IRENA, Abu Dhabi, www.irena.org/publications/2018/Jan/Renewable-power-generation-costsin-2017

Jevons, S.W (1866). The Coal Question; An Inquiry concerning the Progress of the Nation, and the Probable Exhaustion of our Coal-mines, London: Macmillan and Co. $2^{\text {nd }}$ edition.

Kander, A., Malanima, P., and Warde, P. (2013). Power to the People: Energy in Europe over the Last Five Centuries, Princeton, NJ: Princeton University Press.

Lüngen, H.B. (2013). 'Trends for reducing agents in blast furnace operation', Stahlinstitut VDEh, www.dkg.de/akk-vortraege/2013-_-2rd_polnisch_deutsches_symposium/abstract-luengen_reducingagents.pdf

Prost, A. (1991). 'Public and private spheres in France', in Prost, A. and Vincent, G. (eds.), A History of Private Life, Volume V: Riddles of Identity in Modern Times, Cambridge, MA: Belknap Press of Harvard University Press.

Seba, T. (2014). Clean Disruption of Energy and Transportation, San Francisco, CA: Tony Seba.

Smil, V. (2010). Energy Transitions: History, Requirements, Prospects, Santa Barbara, CA: Praeger.

Smil, V. (2016a). Energy Transitions: Global and National Perspectives, Santa Barbara, CA: Praeger. 

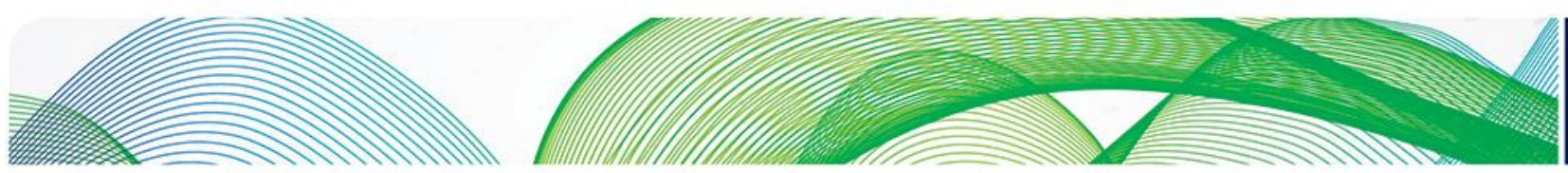

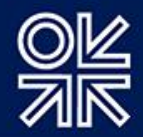

Smil, V. (2016b) ‘Examining energy transitions: a dozen insights based on performance', Energy Research \& Social Science, 22 (2016), 194-7.

Smil, V. (2017). Energy and Civilization: A History, Cambridge, MA: The MIT Press.

Sovacool, B.K. (2016). 'How long will it take? Conceptualizing the temporal dynamics of energy transitions', Energy Research \& Social Science, 13 (2016), 202-15.

Sovacool, B.K. and Geels, F.W. (2016). 'Further reflections on the temporality of energy transitions: A response to critics', Energy Research \& Social Science, 22, 232-7.

Wilson, G. and Staffell, I. (2018). 'Rapid fuel switching from coal to natural gas through effective carbon pricing', Nature Energy, 3, 365-72 